WSRC-TR-99-00096

Publication Date: March, 2000

\title{
REMOVAL OF GADOLINIUM NITRATE FROM HEAVY WATER
}

\author{
By
}

E.W. Wilde, M.B. Goli, C.J. Berry, J.W. Santo Domingo, and H.L. Martin

Westinghouse Savannah River Company

Savannah River Site

Aiken, South Carolina 29808

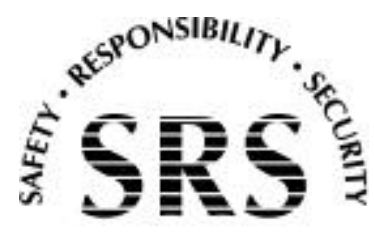




\section{DISCLAIMER}

This report was prepared as an account of work sponsored by an agency of the United States Government. Neither the United States Government nor any agency thereof, nor any of their employees, makes any warranty, express or implied, or assumes any legal liability or responsibility for the accuracy, completeness, or usefulness of any information, apparatus, product or process disclosed, or represents that its use would not infringe privately owned rights. Reference herein to any specific commercial product, process or service by trade name, trademark, manufacturer, or otherwise does not necessarily constitute or imply its endorsement, recommendation, or favoring by the United States Government or any agency thereof. The views and opinions of authors expressed herein do not necessarily state or reflect those of the United States Government or any agency thereof.

This report has been reproduced directly from the best available copy.

Available for sale to the public, in paper, from: U.S. Department of Commerce, National Technical Information Service, 5285 Port Royal Road, Springfield, VA 22161, phone: (800) 553-6847

fax: (703) 605-6900

email: orders@ntis.fedworld.gov

online ordering: http://www.ntis.gov/ordering.htm

Available electronically at http://www.doe.gov/bridge

Available for a processing fee to U.S. Department of Energy and its contractors, in paper, from: U.S. Department of Energy, Office of Scientific and Technical Information, P.O. Box 62, Oak Ridge, TN 37831-0062, phone: (865) 576-8401

fax: (865) 576-5728

email: reports@adonis.osti.gov 


\section{REMOVAL OF GADOLINIUM NITRATE FROM HEAVY WATER}

By

E.W. Wilde, M.B. Goli, C.J. Berry, J.W. Santo Domingo, and H.L. Martin

Westinghouse Savannah River Company

Savannah River Site

Aiken, South Carolina 29808

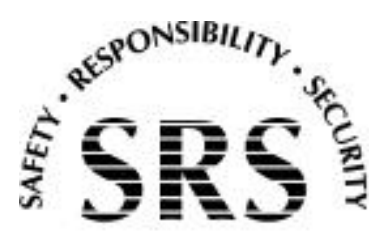




\section{CONTENTS}

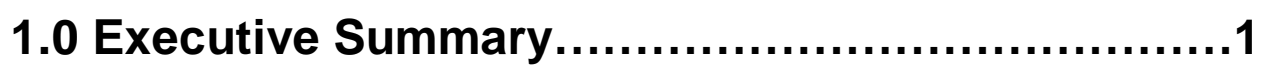

2.0 Introduction and Description of Problem..............3

3.0 Drum Sampling...............................................

4.0 Gadolinium Toxicity Studies............................10

5.0 Precipitation of Gadolinium.............................18

6.0 Microbial Growth and Uptake of Nitrate.............20

7.0 Conceptual Process Design............................24

8.0 Proposed Future Work....................................26

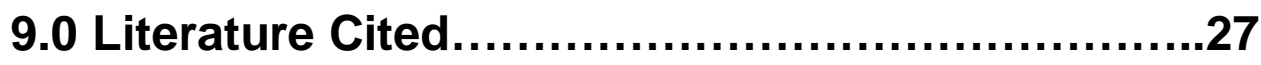

10.0 Acknowledgements.....................................28

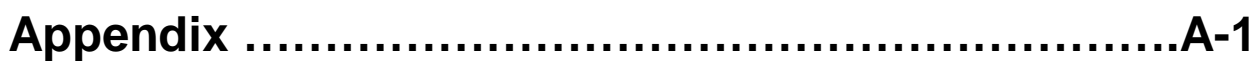




\section{List of Tables}

1. Chemical/Radiological Characterization of Drum Samples:

Parameters, Units and Procedures................................... 5

2. Characterization Data: Drums of Spent Moderator Water.............7

3. Relationship between Gadolinium, Nitrate, and Conductivity in Spent Moderator Drums ........................................ 9

4. Corresponding $\mathrm{Gd}$ and $\mathrm{NO}_{3}$ Concentrations using $\mathrm{Gd}\left(\mathrm{NO}_{3}\right)_{3} \cdot 6 \mathrm{H}_{2} \mathrm{O}$ in Modified BB Media*...

5. Nitrate Concentrations $(\mathrm{mg} / \mathrm{l})$ before and after Inoculation and Growth (1-week) of Algae (Chlorella) in Modified Bold's Basal Media Containing Various Nitrate Salts.

6. Nitrate Removal by Denitrifying Bacteria under Various

Conditions.

\section{List of Figures}

1. Growth of three species of algae at various concentrations of gadolinium.

2. Growth of Chlorella during exposure to various $\mathrm{pH}$ and gadolinium

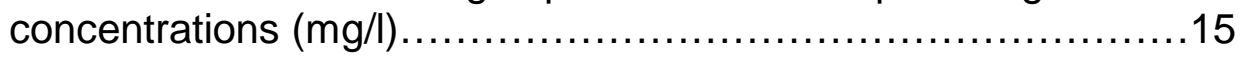

3. Comparative algal growth in four nitrate salt solutions.............17

4. Conceptual process for purifying drums of heavy water

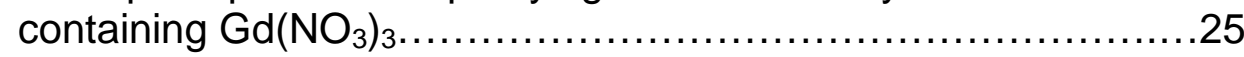




\subsection{Executive Summary}

Work was conducted to develop a cost-effective process to purify 181 55-gallon drums containing spent heavy water moderator $\left(\mathrm{D}_{2} \mathrm{O}\right)$ contaminated with high concentrations of gadolinium nitrate, a chemical used as a neutron poison during former nuclear reactor operations at the Savannah River Site (SRS). These drums also contain low level radioactive contamination, including tritium, which complicates treatment options. Presently, the drums of degraded moderator are being stored on site. It was suggested that a process utilizing biological mechanisms could potentially lower the total cost of heavy water purification by allowing the use of smaller equipment with less product loss and a reduction in the quantity of secondary waste materials produced by the current baseline process (ion exchange).

Microbiological and chemical studies were initiated to evaluate the potential use of bacteria and algae for water purification of the drums. These studies along with recommendations for continued process development work are described herein. Principal components of the study included:

1) chemical and biological characterization of representative drums from the 181 drum inventory,

2) evaluation of the toxicity of gadolinium to various microbes,

3) evaluation of the effectiveness of gadolinium precipitation with phosphate and the hydrate composition of the precipitate, and

4) the comparative growth and nitrate removal capabilities of selected microbes subjected to nitrate salts at various concentrations and with four different anion components.

Results from the drum characterization studies showed substantial variability among drums in terms of $\mathrm{pH}$, conductivity, heavy water content, and gadolinium nitrate concentration. Gadolinium concentrations ranged from $0.09 \mathrm{ppm}$ to $203,800 \mathrm{ppm}$ in eight drums selected for intensive sampling. Biological sampling demonstrated the presence of microorganisms in all eight of these drums and suggested that gadolinium may have a toxic effect on microbes since substantial growth could only be enhanced by nutrient addition in three of four drums with relatively low $(<100 \mathrm{ppm})$ gadolinium concentrations. No significant increase in microbial density occurred in drums with Gadolinium concentrations of $>100 \mathrm{ppm}$ with the addition of nutrients (glucose) to the drum water.

Experiments were then conducted to evaluate the toxicity of gadolinium to algae. Several species were tested for toxicity to various $\mathrm{Gd}$ concentrations at various $\mathrm{pH}$ conditions. At all pH conditions tested, algal growth decreased dramatically between $100 \mathrm{mg} / \mathrm{l}$ and $1000 \mathrm{mg} / \mathrm{l}$. Based on these data it was concluded that algal growth is inhibited at gadolinium concentrations in this range. Since gadolinium levels in drums 
are reportedly as high as $280,000 \mathrm{ppm}$, the use of algae or other microbes to sequester gadolinium and or nitrate in the absence of other treatment does not seem feasible.

Since the toxicity experiments clearly demonstrated that Gadolinium is toxic to microorganisms at the higher concentrations present in some of the drums, we evaluated removal of the gadolinium by precipitation prior to nitrate removal.

Experiments using $\mathrm{Na}_{3} \mathrm{PO}_{4} \cdot 12 \mathrm{H}_{2} \mathrm{O}$ as the precipitating agent demonstrated that virtually all dissolved gadolinium can be precipitated in a single precipitation step, that takes less than 30 minutes and can be done by a solid or liquid (solution) of $\mathrm{Na}_{3} \mathrm{PO}_{4}$. Dry or wet sodium phosphate worked equally well for the precipitation of Gadolinium as $\mathrm{GdPO}_{4}$. The yield was close to $100 \%$ in both cases. Analyses of the precipitate indicated that it contained $10.43 \%$ phosphorus and $7.58 \% \mathrm{H}_{2} \mathrm{O}$ which corresponds to a compound like $\mathrm{GdPO}_{4} \cdot 1 \mathrm{H}_{2} \mathrm{O}$. Although it appeared that a precipitation step would result in a small loss of heavy water due to hydrate formation within the precipitate, that heavy water could be recovered by heating the hydrate to $150^{\circ} \mathrm{C}$ and condensing the vapor.

The final phase of the study involved testing the ability of selected microbes to remove nitrate from simulated contaminated moderator drum water following removal of gadolinium. Algal growth was better in nitrate salt solutions with $\mathrm{Na}, \mathrm{K}$ and $\mathrm{NH}_{4}$ as the cation compared to $\mathrm{GdNO}_{3}$. Substantial nitrate reduction in response to algal growth was evident in many cases, especially at the lower salt concentrations. However, valid comparisons between algal growth and nitrate removal could not be made for many of the test conditions because of unexplainable variation in nitrate measurement results. Thus, additional experiments need to be conducted before firm conclusions can be made regarding comparative nitrate removal.

Based on the results of the studies, a four-step conceptual process has been developed. The gadolinium is removed by chemical treatment (e.g. precipitation with potassium phosphate) and subsequently processed for potential re-sale. Residual potassium nitrate is removed by a combination of electrochemical and biological methods. Nitrate is reduced to extremely low (ppb) levels by metabolically mediated uptake into live algal cells. The algal biomass is separated from the water by centrifugation or filtration, dried, and disposed of by incineration.

The proposed process has three significant advantages over the "baseline" technology, ion-exchange: (1)Gadolinium can be recovered and potentially sold as a valuable resource, rather than being included in the secondary waste stream, (2) less dilution of heavy water occurs in the process resulting in improved economics when the purified heavy water is sold for use in commercial reactors (3) secondary waste will be reduced more than three-hundred-fold (from approximately $300 \%$ of the original volume to $<1 \%$ of the original volume). Additional process development is necessary to advance from the proof-of-concept stage to a working process that will convert a legacy waste into a valuable resource. 


\subsection{Introduction and Description of Problem}

Nuclear reactors were operated for approximately 30 years at the Savannah River Site (SRS) near Aiken, SC to produce nuclear weapons materials for national defense. Throughout this period, a heavy water solution of gadolinium nitrate was utilized in a standby emergency shutdown system that could inject this chemical into the reactor moderator coolant water. The chemical was used for this purpose because the high neutron absorption cross sections of some gadolinium isotopes make gadolinium salts such as $\mathrm{GdNO}_{3}$ effective in controlling nuclear activity in aqueous systems (Baumann, 1980; Gilbert et al., 1985, Rodenas et al. 1990). Currently, there is an inventory of approximately 18155 -gallon drums (37,680 liters overall) of this degraded heavy water containing gadolinium nitrate. The sale of some of the heavy water inventory at SRS for use in commercial nuclear power reactors is being negotiated, but the degraded heavy water containing $\mathrm{GdNO}_{3}$ has been rejected. Thus, purification and up-grade is required for sale of this heavy water.

Existing gadolinium purification technology by ion exchange would generate large volumes of waste. Manufacture of the needed quantity of special resin, assembly of process equipment, and drum purification, with frequent resin bed changes and moderator dilution by flushes, would be required. Alternative treatment by the purification evaporator is not possible because nitrate salts would quickly foul the pot. Tritium in the evaporator flush water would complicate treatment and disposal. Much heavy water would be lost to the hydrated salt waste in the evaporator pot.

Failing to purify the $\mathrm{GdNO}_{3}$-contaminated heavy water could be very costly. Because of the tritium content, storage of this high conductivity aqueous waste in stainless steel drums remains a liability and significant expense. A waste treatment/stabilization process would require development and would generate an even larger waste volume for costly disposal. In contrast, purification of the degraded heavy water such that it can be sold provides funds for a portion of the treatment and waste disposal expense. Rather than becoming a waste liability, the moderator becomes available for commercial nuclear power generation. Furthermore, the gadolinium that could be recovered may have commercial use.

Although this project focuses on the problems at SRS with the end user being the Spent Fuel Storage Division, Gadolinium nitrate is used as a neutron absorbent in heavy water nuclear power reactors world-wide and a cost-effective process for purification and reuse has considerable potential usage. 


\subsection{Drum Sampling}

A total of 99 of the subject drums were sampled in December 1996 and January, 1997. All 99 were assayed for conductivity, pH tritium and gadolinium. Ninety-two (92) were assayed for mole $\% \mathrm{D}_{2} \mathrm{O}$ and 13 were assayed for nitrate. The results of these analyses were reviewed prior to selecting eight drums for more extensive chemical characterization and microbiological characterization in the present study. The eight drums that were selected represent a wide range of conditions. These conditions included relatively high and low values for gadolinium, $\mathrm{pH}$, conductivity and $\% \mathrm{D}_{2} \mathrm{O}$. One-liter samples were collected from each of the eight drums on 2/12/98. Aliquots of these drum samples were subjected to both chemical (including radiological) and microbiological analyses. The chemical/radiological analyses were conducted by SRTC/ADS personnel while microbiological analyses were conducted by SRTC/EBS personnel.

\section{Methodology}

Chemical parameters and the procedures used for each analysis are shown in Table 1. Water samples from Par Pond were processed along with the drum samples to provide reference data for microbial concentration quantities.

Aliquots from the drums were subjected to the following microbiological processing and analyses techniques:

Spread Plates: Duplicate plates were prepared using 10 microliters (ul) and $100 \mathrm{ul}$ inoculums taken from each drum sample. The plate agar consisted of a $1 \%$ peptonetryptone-yeast-glucose mixture without cyclohexane. A glass "L" shaped glass rod and turntable were used to spread the inoculum evenly over the entire surface of the agar by rotating the plate and moving the rake back and forth. The glass rod was alcohol sterilized and flamed between each plate. The plates were covered and incubated in an inverted position at room temperature until plate counts were performed.

Direct Total Counts: Microscopic counts of cells were performed by spotting fifty microliters (ul) of well-mixed water onto toxoplasmosis slides and heat fixing at $65^{\circ} \mathrm{C}$ for 12 minutes. The samples were then stained with either fluorescein isothiocyanate (FITC) solution $(0.04 \%$ FITC in a $0.5 \mathrm{M} \mathrm{NaCO} 3$ - phosphate buffer, $\mathrm{pH} 7.2)$ or acridine orange $(\mathrm{AO})(0.1 \% \mathrm{AO}$ in phosphate buffer) for two minutes, rinsed with deionized prefiltered $(0.2 \mu \mathrm{m}$ pore size) water and air dried at room temperature. Stained microbial cells were counted using a Zeiss epifluorescence microscope and appropriate filter set. After counting the cells on each slide, the cellular density was calculated based on the sample volume, the area of each field for the microscope, and the total number of fields counted. Results are presented as a total count per milliliter and represents all the microorganisms, both living and dead, that were present in the collected water sample. 
Table 1. Chemical/Radiological Characterization of Drum Samples: Parameters, Units and Procedures

\begin{tabular}{|l|l|}
\hline \multicolumn{1}{|c|}{ Parameter } & \multicolumn{1}{c|}{ Methodology } \\
\hline $\mathrm{pH}(\mathrm{units})$ & Combination pH electrode \\
\hline $\mathrm{Gd}(\mathrm{mg} / \mathrm{l})$ & Inductively Coupled Argon Plasma Spectroscopy \\
\hline $\mathrm{D}_{2} \mathrm{O}(\mathrm{mole} \%)$ & Infrared Spectroscopy \\
\hline Conductivity $(\mu \mathrm{Mhos})$ & Electrolytic method \\
\hline $\mathrm{NO} 3(\mathrm{mg} / \mathrm{l})$ & lon Chromatography \\
\hline $\mathrm{Ca}(\mathrm{mg} / \mathrm{l})$ & lon Chromatography \\
\hline $\mathrm{Fe}(\mathrm{mg} / \mathrm{l})$ & $\begin{array}{l}\text { Inductively Coupled Plasma Emission } \\
\text { Spectroscopy }\end{array}$ \\
\hline $\mathrm{Mg}(\mathrm{mg} / \mathrm{l})$ & $\begin{array}{l}\text { Inductively Coupled Plasma Emission } \\
\text { Spectroscopy }\end{array}$ \\
\hline $\mathrm{Mn}(\mathrm{mg} / \mathrm{l})$ & $\begin{array}{l}\text { Inductively Coupled Plasma Emission } \\
\text { Spectroscopy }\end{array}$ \\
\hline $\mathrm{Mo}(\mathrm{mg} / \mathrm{l})$ & $\begin{array}{l}\text { Inductively Coupled Plasma Emission } \\
\text { Spectroscopy }\end{array}$ \\
\hline Zn (mg/l) & $\begin{array}{l}\text { Inductively Coupled Plasma Emission } \\
\text { Spectroscopy }\end{array}$ \\
\hline $\mathrm{K}(\mathrm{ppm})$ & Atomic Absorption Spectrometry \\
\hline Na (ppm) & lon Chromatography \\
\hline Alkalinity (mg/l CaCO3) & Atomic Absorption Spectrometry \\
\hline Chloride (ug/ml) & lon Chromatography \\
\hline Fluoride (ug/ml) & lon Chromatography \\
\hline Formate (ug/ml) & lon Chromatography \\
\hline Nitrate (ug/ml) & lon Chromatography \\
\hline Nitrite (ug/ml) & lon Chromatography \\
\hline Oxalate (ug/ml) & lon Chromatography \\
\hline Phosphate (ug/ml) & lon Chromatography \\
\hline Sulfate (ug/ml) & lon Chromatography \\
\hline Ammonium ion (ug/ml) & $\begin{array}{l}\text { Inductively Coupled Plasma Emission } \\
\text { Spectroscopy }\end{array}$ \\
\hline Inorganic carbon (ppm) & Total Organic Carbon Analyzer \\
\hline Organic carbon (ppm) & Total Organic Carbon Analyzer \\
\hline Beta count (dpm/ml) & Liquid Scintillation Counting \\
\hline Tritium count (uCi/ml) & Liquid scintillation counting \\
\hline Alpha count (dpm/ml) & Liquid scintillation counting \\
\hline & \\
\hline
\end{tabular}


Nutrient Addition: Nutrient additions were made to the drum samples by first transferring $7.0 \mathrm{ml}$ of each drum sample into sterile $15-\mathrm{ml}$ centrifuge tubes. Then $250 \mathrm{ul}$ of a glucose solution was added to each vial to yield a final glucose concentration of $0.34 \%$. The vials were tightly capped and placed on a rotating shaker for 72 hours. The samples were then analyzed using the direct count method described above.

\section{Results and Discussion}

Complete results of chemical and microbiological analyses of the drum samples are shown in Table 2. The samples with the highest gadolinium concentrations generally displayed proportionally higher concentrations of $\mathrm{NO}_{3}$, conductivity, $\mathrm{Fe}, \mathrm{Mg}, \mathrm{Mn}, \mathrm{Mo}, \mathrm{P}$, $\mathrm{Zn}, \mathrm{K}$, and $\mathrm{Na}$ and organic carbon.

Drums with relatively high gadolinium concentrations also tended to have the lowest quantities of bacteria. Although only three of the drum samples produced culturable bacteria on $1 \%$ PTYG agar, bacteria (either viable or nonviable), were present in all drums. Initially, their total densities ranged from a little higher than in tap water to nearly as high as in a water sample from Par pond. Thus, the data indicate that some bacteria are present in all of the drums, including those containing $>99 \% \mathrm{D}_{2} \mathrm{O}$ with nitrate and gadolinium concentrations greater than $200,000 \mathrm{mg} / \mathrm{l}$ (Table 2).

The microbial density increased in six of the eight drum samples, as measured using the direct count method, when glucose was added to the drum samples. Bacteria densities increased more than two orders of magnitude with nutrient addition in three of the samples. All of these contained less than $100 \mathrm{ppm}$ gadolinium. Cells in many of these samples were larger and/or in the process of dividing when viewed under the microscope indicating the presence of actively growing cells. The largest increase in cellular density occurred with the sample from drum \#15435, which had a very low gadolinium concentration. This sample also had the largest number of viable bacteria as determined using the spread plate method. The addition of an organic carbon source, glucose, appeared to stimulate the growth of the bacteria that were already present in the samples.

Samples with little or no increase in bacterial density tended to contain the highest amounts of gadolinium. However, these samples were difficult to enumerate and the results are subject to error because the samples did not evaporate completely and left a slime layer on the microscope slides after being rinsed. The additional gadolinium in the sample appeared to increase the viscosity of the sample and increase its boiling point.

Although the presence of large amounts ( $>5000 \mathrm{ppm}$ ) of gadolinium may have affected either the growth of the bacteria or the ability to enumerate the cells using our direct count methods, dividing cells were observed in the sample from drum \#18156, and viable cells were measured in drum sample \#13749. This indicates that some bacteria 
Table 2. Characterization Data: Drums of Spent Moderator Water

\begin{tabular}{|c|c|c|c|c|c|c|c|c|c|c|}
\hline Drum \# & 18156 & 15208 & 15817 & 4600 & 15793 & 15861 & 15435 & 13749 & Reference & water \\
\hline $\begin{array}{l}\text { Microbiologic } \\
\text { al data }\end{array}$ & & & & & & & & & $\begin{array}{r}\text { Tap } \\
\text { Water }\end{array}$ & \begin{tabular}{|l} 
Par Pond \\
\end{tabular} \\
\hline $\begin{array}{c}\text { Direct Count } \\
\text { Cells/ml }\end{array}$ & $1.24 \mathrm{E}+05$ & $6.14 \mathrm{E}+05$ & $4.74 \mathrm{E}+04$ & $1.29 \mathrm{E}+05$ & $5.57 \mathrm{E}+04$ & $8.25 \mathrm{E}+03$ & $1.22 \mathrm{E}+06$ & $9.28 \mathrm{E}+03$ & $2.06 \mathrm{E}+03$ & $1.93 \mathrm{E}+06$ \\
\hline $\begin{array}{c}\text { Spread Plate } \\
\mathrm{CFU} / \mathrm{ml}\end{array}$ & $0.00 \mathrm{E}+00$ & $2.00 \mathrm{E}+01$ & $0.00 \mathrm{E}+00$ & $0.00 \mathrm{E}+00$ & $0.00 \mathrm{E}+00$ & $0.00 \mathrm{E}+00$ & $6.35 \mathrm{E}+03$ & $6.20 \mathrm{E}+02$ & & \\
\hline \begin{tabular}{|c|}
$72 \mathrm{hr}$. Nutrient \\
Cell//ml
\end{tabular} & $3.44 \mathrm{E}+05$ & $2.03 \mathrm{E}+03$ & $3.80 \mathrm{E}+04$ & $2.08 \mathrm{E}+05$ & $1.43 \mathrm{E}+06$ & $1.38 \mathrm{E}+06$ & $>1.0 \mathrm{E}+08$ & $2.44 \mathrm{E}+04$ & & \\
\hline \multicolumn{9}{|l|}{\begin{tabular}{|l|}
$\begin{array}{l}\text { Chemical } \\
\text { data }\end{array}$ \\
\end{tabular}} & & \\
\hline Gd ppm & 202500 & 203800 & 0.09 & 142 & 97 & 0.5 & 0.26 & 6118 & & \\
\hline Nitrate $(\mathrm{mg} / \mathrm{l})$ & 183936 & 279985 & $<1$ & 179 & 63 & $<1$ & $<1$ & 5954 & & \\
\hline $\mathrm{PH}$ & 1.63 & 5.36 & 6.14 & 3.62 & 6.79 & 6.34 & 5.59 & 6.66 & & \\
\hline $\mathrm{D}_{2} 0 \%$ & 78.17 & 99.59 & 98.73 & 98.54 & 99.65 & 99.47 & 99.17 & 2.99 & & \\
\hline Cond. $(\mu \mathrm{mhos})$ & 84400 & 97500 & 4.07 & 394 & 199 & 1.4 & 10.8 & 9020 & & \\
\hline $\mathrm{Ca}(\mathrm{mg} / \mathrm{l})$ & 8.6 & 10.48 & 0.15 & 0.09 & 0.07 & 0.07 & 0.21 & 7.29 & & \\
\hline $\mathrm{Fe}(\mathrm{mg} / \mathrm{l})$ & 24.62 & 8.53 & 0.06 & 0.15 & 0.02 & 0.01 & 0.02 & 0.24 & & \\
\hline $\mathrm{Mg}(\mathrm{mg} / \mathrm{l})$ & 0.92 & 0.43 & 0.05 & 0.04 & 0.01 & 0.02 & 0.04 & 0.55 & & \\
\hline $\mathrm{Mn}(\mathrm{mg} / \mathrm{l})$ & 5.21 & 5.06 & 0.06 & 0.02 & $<0.01$ & $<0.01$ & $<0.01$ & 0.25 & & \\
\hline Mo (mg/l) & 50.9 & 63.91 & 0.56 & 0.06 & 0.03 & $<0.01$ & $<0.01$ & 2.52 & & \\
\hline $\mathrm{P}(\mathrm{mg} / \mathrm{l})$ & 50.53 & 64.25 & 0.51 & 0.07 & 0.03 & $<0.02$ & 0.02 & 2.27 & & \\
\hline $\mathrm{Zn}(\mathrm{mg} / \mathrm{l})$ & 20.05 & 3.66 & 0.12 & 0.13 & 0.01 & 0.01 & 0.03 & 0.28 & & \\
\hline $\mathrm{K}(\mathrm{mg} / \mathrm{l}))$ & 0.545 & 0.765 & $<0.195$ & $<0.195$ & $<0.195$ & $<0.195$ & $<0.195$ & 1.19 & & \\
\hline $\mathrm{Na}(\mathrm{mg} / \mathrm{l})$ & 2.024 & 185.724 & 0.869 & 5.599 & $<0.198$ & $<0.198$ & 0.594 & 132.66 & & \\
\hline $\begin{array}{c}\text { Alkalinity } \\
(\mathrm{mg} / \mathrm{l})\end{array}$ & $<250$ & $<250$ & $<250$ & $<250$ & $<250$ & $<250$ & $<250$ & $<250$ & & \\
\hline Chloride $(\mu \mathrm{g} / \mathrm{l})$ & $<200$ & $<200$ & $<200$ & $<2$ & $<0.2$ & $<0.2$ & 1 & $<200$ & & \\
\hline Fluoride $(\mu \mathrm{g} / \mathrm{l})$ & $<200$ & $<200$ & $<200$ & $<2$ & $<0.2$ & $<0.2$ & $<0.2$ & $<200$ & & \\
\hline Formate $(\mu \mathrm{g} / \mathrm{l})$ & $<1000$ & $<1000$ & $<1000$ & $<10$ & $<1$ & $<1$ & $<1$ & $<1000$ & & \\
\hline Nitrite $(\mu \mathrm{g} / \mathrm{l})$ & $<1000$ & $<1000$ & $<1000$ & $<10$ & $<1$ & $<1$ & $<1$ & $<1000$ & & \\
\hline Oxalate $(\mu \mathrm{g} / \mathrm{l})$ & $<1000$ & $<1000$ & $<1000$ & $<10$ & $<1$ & $<1$ & $<1$ & $<1000$ & & \\
\hline $\begin{array}{c}\text { Phosphate } \\
(\mu \mathrm{g} / \mathrm{l})\end{array}$ & $<1000$ & $<1000$ & $<1000$ & $<10$ & $<1$ & $<1$ & $<1$ & $<1000$ & & \\
\hline Sulfate $(\mu \mathrm{g} / \mathrm{l})$ & $<500$ & $<500$ & $<500$ & $<5$ & $<0.5$ & $<0.5$ & $<0.5$ & $<500$ & & \\
\hline $\begin{array}{c}\text { Ammonium ion } \\
(\mu \mathrm{g} / 1\end{array}$ & $<10$ & $<10$ & $<10$ & $<10$ & $<10$ & $<10$ & $<10$ & $<10$ & & \\
\hline $\begin{array}{c}\text { Inorganic } \\
\text { carbon }(\mathrm{mg} / \mathrm{l}) \\
\end{array}$ & 0.246 & 10 & 0.319 & 0.259 & 0.223 & 0.182 & 0.104 & 2 & & \\
\hline $\begin{array}{c}\text { Organic carbon } \\
(\mathrm{mg} / \mathrm{l})\end{array}$ & 44 & 26 & 14 & 14 & 12 & 6 & 10 & 6 & & \\
\hline \multicolumn{9}{|l|}{$\begin{array}{l}\text { Radiological } \\
\text { Data }\end{array}$} & & \\
\hline $\begin{array}{c}\text { Beta count } \\
\text { (dpm/ml) }\end{array}$ & $4.57 \mathrm{E}+09$ & $5.66 \mathrm{E}+07$ & $7.18 \mathrm{E}+09$ & $5.33 \mathrm{E}+09$ & $4.29 \mathrm{E}+09$ & $7.32 \mathrm{E}+09$ & $4.66 \mathrm{E}+09$ & $4.39 \mathrm{E}+08$ & & \\
\hline $\begin{array}{c}\text { Tritium count } \\
(\mathrm{uCi} / \mathrm{ml})\end{array}$ & $2.06 \mathrm{E}+03$ & $2.55 \mathrm{E}+01$ & $3.23 \mathrm{E}+03$ & $2.40 \mathrm{E}+03$ & $1.93 \mathrm{E}+03$ & $3.30 \mathrm{E}+03$ & $2.10 \mathrm{E}+03$ & $1.98 \mathrm{E}+02$ & & \\
\hline $\begin{array}{c}\text { Alpha count } \\
\text { (dpm/ml) }\end{array}$ & $<1.59 \mathrm{E}+05$ & $<1.59 \mathrm{E}+05$ & $<1.59 \mathrm{E}+05$ & $<1.59 \mathrm{E}+05$ & $<1.59 \mathrm{E}+05$ & $<1.59 \mathrm{E}+05$ & $<1.59 \mathrm{E}+05$ & $<1.59 \mathrm{E}+05$ & & \\
\hline
\end{tabular}


are viable in some environments with very high levels of gadolinium.

In summary, microbiological sampling demonstrated the presence of microorganisms in all eight of the drums sampled and suggested that gadolinium may have a toxic effect on microbes since substantial growth could only be enhanced by nutrient addition in three of four drums with relatively low $(<100 \mathrm{ppm})$ gadolinium concentrations. No significant increase in microbial density occurred in drums with Gadolinium concentrations of $>100 \mathrm{ppm}$ with the addition of nutrients (glucose) to the drum water.

Table 3 shows the concentrations of gadolinium, NQ, and conductivity along with the expected levels of nitrate based on the gadolinium measurements and the molecular weights of the elements in the $\mathrm{Gd}(\mathrm{NQ})_{3}{ }_{3} 6 \mathrm{H}_{2} \mathrm{O}$ compound used in the reactor process where the water in the drums originated. Gadolinium, nitrate, and conductivity were strongly correlated with each other. Expected (calculated) and measured values of nitrate were generally similar. There was no clear evidence from these analyses that bacteria were reducing nitrate in the drums since some of the drums had measured nitrate levels higher than expected values based entirely on the stoichiometry (Table 3). 
Table 3. Relationship between Gadolinium, Nitrate, and Conductivity in Spent Moderator Drums

\begin{tabular}{|c|c|c|c|c|}
\hline Drum \# & $\mathrm{Gd}(\mathrm{mg} / \mathrm{l})$ & $\begin{array}{l}\mathrm{NO}_{3}(\mathrm{mg} / \mathrm{l} \\
\text { Expected* }\end{array}$ & $\begin{array}{l}\mathrm{NO}_{3}(\mathrm{mg} / \mathrm{l}) \\
\text { Measured }\end{array}$ & $\begin{array}{l}\text { Conductivity } \\
\text { (umhos) }\end{array}$ \\
\hline 15208 & 203800 & 241503 & 279985 & 97500 \\
\hline 18156 & 202500 & 239963 & 183936 & 84400 \\
\hline 13749 & 6118 & 7250 & 5954 & 9020 \\
\hline 4600 & 142 & 168 & 179 & 394 \\
\hline 15793 & 97 & 115 & 63 & 199 \\
\hline 15861 & 0.5 & 0.6 & $<1$ & 1.4 \\
\hline 15435 & 0.26 & 0.3 & $<1$ & 10.8 \\
\hline 15817 & 0.09 & 0.1 & $<1$ & 4.1 \\
\hline
\end{tabular}

*Based on molecular weight ratios for $\mathrm{Gd}$ and NQin $\mathrm{Gd}\left(\mathrm{NO}_{3}\right)_{3} \cdot 6 \mathrm{H}_{2} \mathrm{O}$ 


\subsection{Gadolinium Toxicity Studies}

Metals are often toxic to microbes when present at concentrations substantially higher than natural environmental levels. Therefore, it was hypothesized that $\mathrm{Gd}$ may be toxic to selected microorganisms (algae and bacteria) at the very high concentrations present in most of the drums. The microbial characterization of the drum samples also suggested the presence of gadolinium toxicity to microbes because viable microbes were rare or absent from the drums with the highest Gd concentrations. To assess the feasibility of utilizing an in-drum biological treatment process for remediation, studies were designed to evaluate the capability of selected organisms to grow in GdNot concentrations bracketing the levels present in the drums requiring purification.

\section{Methods}

Three experiments were conducted to evaluate the toxicity of gadolinium to algae. Experimental designs for the three are summarized in the Appendix (Tables A-1 to A-3). In the initial experiment, four species of algae were inoculated into standard culture media with and without GdNQ substituted for conventional nitrate (e.g. NaNQ) to provide $\mathrm{GdNO}_{3}$ at concentrations resulting in Gd concentrations of 0, 10, 100, 1,000, $10,000,80,000$ and 260,000 ppm (thus, bracketing the quantities in all of the drums requiring treatment). Relative concentrations of Gd and NQbased on elemental atomic weights and the hydrate form of the gadolinium nitrate used in the experiments are shown in Table 4. Gd and NQ concentrations of the media were measures at the start of the experiment and after one and two weeks. Algal cultures includeahlorella pyrenoidosa, Scenedesmus quadricauda, Closterium sp. and Cyanidium caldarum. All four strains were obtained from the Carolina Biological Supply Company, Burlington, NC, USA. Chlorella and Scenedesmus were grown in modified Bold Basal (BB) medium (Nichols and Bold 1965). Closterium was grown in Alga Gro Freshwater Medium and Cyanidium in Doemel's Cyanidium medium (Carolina Biological Supply Co., 1978). These species were selected on the basis of one or more of the following criteria:

1. on hand or readily obtainable

2. known or suspected ability to grow in high $\mathrm{DO}$ concentrations

3. known or suspected high capability to assimilate nitrate

Culture media was prepared in $25 \mathrm{ml}$ batches in $50 \mathrm{ml}$ flasks prior to being autoclave sterilized. Flasks were subsequently inoculated with 60 Qul of algal culture in accordance with the scheme shown in Table A-1. The flasks were then placed in a Pschrotherm shaker/ incubator (New Brunswick Scientific) for two weeks at $2 \mathbb{C}$, with a $12 \mathrm{~h}$ light $\left(200 \mu \mathrm{E}^{-2} \mathrm{~s}^{-1}\right): 12 \mathrm{~h}$ dark illumination regime and $100 \mathrm{rpm}$ rotation.

Control flasks, not inoculated with algae but otherwise treated identically with all 
Table 4. Corresponding $\mathrm{Gd}$ and $\mathrm{NO}_{3}$ Concentrations using $\mathrm{Gd}\left(\mathrm{NO}_{3}\right)_{3} \cdot 6 \mathrm{H}_{2} \mathrm{O}$ in Modified BB Media*

\begin{tabular}{|c|c|c|}
\hline Amount $\mathrm{Gd}\left(\mathrm{NO}_{3}\right)_{3} \cdot 6 \mathrm{H}_{2} \mathrm{O} / \mathrm{l}$ added & Gd (mg/l) & $\mathrm{NO}_{3}(\mathrm{mg} / \mathrm{l})$ \\
\hline $0.0286 \mathrm{~g}$ & 10 & 11.85 \\
\hline $0.2859 \mathrm{~g}$ & 100 & 118.5 \\
\hline $2.8593 \mathrm{~g}$ & 1,000 & 1,184 \\
\hline $28.5934 \mathrm{~g}$ & 10,000 & 11,847 \\
\hline $228.7472 \mathrm{~g}$ & 80,000 & 94,777 \\
\hline $743.4180 \mathrm{~g}$ & 260,000 & 308,022 \\
\hline
\end{tabular}

${ }^{*}$ Based on molecular weight ratios for $\mathrm{Gd}$ and $\mathrm{NQ}$ in $\mathrm{Gd}\left(\mathrm{NO}_{3}\right)_{3} \cdot 6 \mathrm{H}_{2} \mathrm{O}$ 
treatment conditions, were examined for nitrate and gadolinium concentrations at the start and conclusion of all three experiments.

The experimental design for Experiment \#1 is shown in Appendix Table A-1. Densities of live algae were determined by examining aliquots from the flasks with an inverted microscope using fluorescence microscopy which allows the differentiation of live and dead cells by the detection of chlorophyll fluorescence when cells are subjected to excitation by blue or green light (Wilde and Fliermans,1979, Wood et al. 1985, Tsuji et al. 1986). Density estimates were made by randomly counting fields until a minimum of 400 cells were tabulated. These counts were performed after incubation periods of oneand two-weeks. After $250 \mu$ laliquots were collected from the flasks for microscopical observations, the remaining liquid was filtered $(0.45 \mathrm{~m}$ pore size). The filters were labeled, dried and photographed. The relative amount of algae observed on the dried filters was compared to the quantitative count data.

Experiment 2 was conducted to further elucidate the toxicity of GdNO3 to algae. Based on the results of Experiment 1, the range of Gadolinium that the algae were exposed to was decreased and two additional algal strains were evaluated. These were isolates of the species, Mastigocladus laminosus, a thermophilic blue green alga. These isolates were derived from SRS reactor effluent streams and cultured in Medium ND (Castenholz 1982). Three different pH levels, 3.5, 4.5, and 5.5 were also compared (Table A-2). Algae were enumerated at the start of the experiment and at one- and twoweek intervals. Otherwise, experimental protocols were identical to those described for Experiment 1.

Experiment \#3 (Table A-3) was conducted to determine: (1) comparative toxicity of GdNO3, NaNO3, KNO3 and NH4NO3 to algae, (2) whether algae can live in high nitrate concentrations if $\mathrm{Gd}$ is replaced by other metals or ammonium, and (3) nitrate uptake by algae in relation to algal growth and nitrate compound form at various concentrations. Modified BB Medium was formulated to contain 10, 100, 1000, and $10,000 \mathrm{mg} / \mathrm{l}$ of $\mathrm{Gd}$ as $\mathrm{GdNO}_{3}, \mathrm{Na}$ as $\mathrm{NaNO}_{3}, \mathrm{~K}$ as $\mathrm{KNO}_{3}$, and $\mathrm{NH}_{4}$ as $\mathrm{NH}_{4} \mathrm{NO}_{3}$. Triplicate samples containing each medium were inoculated with 690 of a Chlorella vulgaris suspension and algal concentrations were determined immediately and after one week of incubation under pschrotherm incubator conditions previously described.

Several denitrifying bacteria strains were obtained from the American Type Culture Collection (ATTC) and evaluated for their ability to grow and remove nitrate in liquid culture media (5\% peptone tripticase yeast glucose) spiked with salt concentrations ranging from 0 to 2000 ppm Gd. Following sterilization of the media and inoculation of microbes in culture tubes, the samples were placed on shaking platforms and checked visually at regular intervals (at least once every two days) for visible growth. Tubes that 
showed indications of growth were measured for turbidity and compared with uninoculated control tubes. Samples showing clear signs of growth were subsequently analyzed for nitrate content.

\section{Results and Discussion}

Comprehensive data results from the three algae experiments are presented in Appendix Tables A-4 to A-6. Observations of the relative amounts of algae on the dried filters led to the same conclusions regarding growth as the quantitative counts utilizing the microscope. Thus, labeling and photographing of the dried filters provided a quick screening method to qualitatively observe and document relative quantities of algal growth. This procedure eliminates the need to conduct laborious microscopic counts for all samples, particularly those where algal growth is clearly inferior based on naked eye assessments. Use of this technique allowed us to quickly eliminate several algal strains and media conditions from further consideration during the initial screening phase of process development.

The initial experiment showed thatChlorella vulgaris was more tolerant to gadolinium nitrate than Scenedesmus quadricauda or Cyanidium caldarum (Figure 1). The microscopical examinations also revealed some viable algal cells at gadolinium concentrations up to $260,000 \mathrm{mg} / \mathrm{l}$. However, growth was greatly impeded at gadolinium concentrations between $100 \mathrm{mg} / \mathrm{l}$ and $1000 \mathrm{mg} / \mathrm{l}$. The growth data in Figure 1 represent the change in algal populations between the first and second week of inoculation in the media. Figure 2 shows the amount ochlorella growth in each of two consecutive 1-week periods when exposed to various concentrations of $\mathrm{Gd}$ and $\mathrm{pH}$ with $\mathrm{BB}$ media. At all $\mathrm{pH}$ conditions tested, algal growth decreased dramatically between $100 \mathrm{mg} / \mathrm{l}$ and $1000 \mathrm{mg} / \mathrm{l}$. These data support the conclusion that algal growth is inhibited at concentrations in this range.

At $\mathrm{pH} 4.5$ and 5.5, Chlorella grew much better when gadolinium concentrations were 0 and $100 \mathrm{mg} / \mathrm{l}$ compared to a gadolinium concentration of $10 \mathrm{mg} / \mathrm{l}$ (Figure 2) (This was also evident in Figure 1). This result, which may appear as a data anomaly at first glance, can be explained by the methodology. The $0 \mathrm{mg} / \mathrm{l}$ gadolinium samples were prepared with the standard modified BB media formulation which contains $182.5 \mathrm{mg} / \mathrm{l}$ of nitrate as $\mathrm{NaNO}_{3}$; whereas, the formulations for 10 to $10000 \mathrm{mg} / \mathrm{l}$ gadolinium samples were prepared by substituting $\mathrm{Gd} / \mathrm{NQ}_{3}$ in place of sodium nitrate. Thus, the 0,10 , and $100 \mathrm{mg} / \mathrm{l}$ gadolinium formulations contained $182.5,11.9$, and $118.5 \mathrm{mg} / \mathrm{l}$ nitrate, respectively and the lower growth at $10 \mathrm{mg} / \mathrm{l} \mathrm{Gd}$, relative to the $0 \mathrm{mg} / \mathrm{l}$ and $100 \mathrm{mg} / \mathrm{l}$ concentrations was most likely due to nitrate limitation rather than gadolinium toxicity. The relationship between nitrate uptake and algal growth is further discussed in Section 6.0. Growth was substantially higher in the second week of incubation than in the first week with the exception of the $10 \mathrm{mg} / \mathrm{l} \mathrm{Gd}$ exposures at $\mathrm{pH} 4.5$ and $\mathrm{pH}$ 5.5. Once again, the lower growth at $10 \mathrm{mg} / \mathrm{l} \mathrm{Gd}$ is thought to be due to the depletion of nitrate after the 


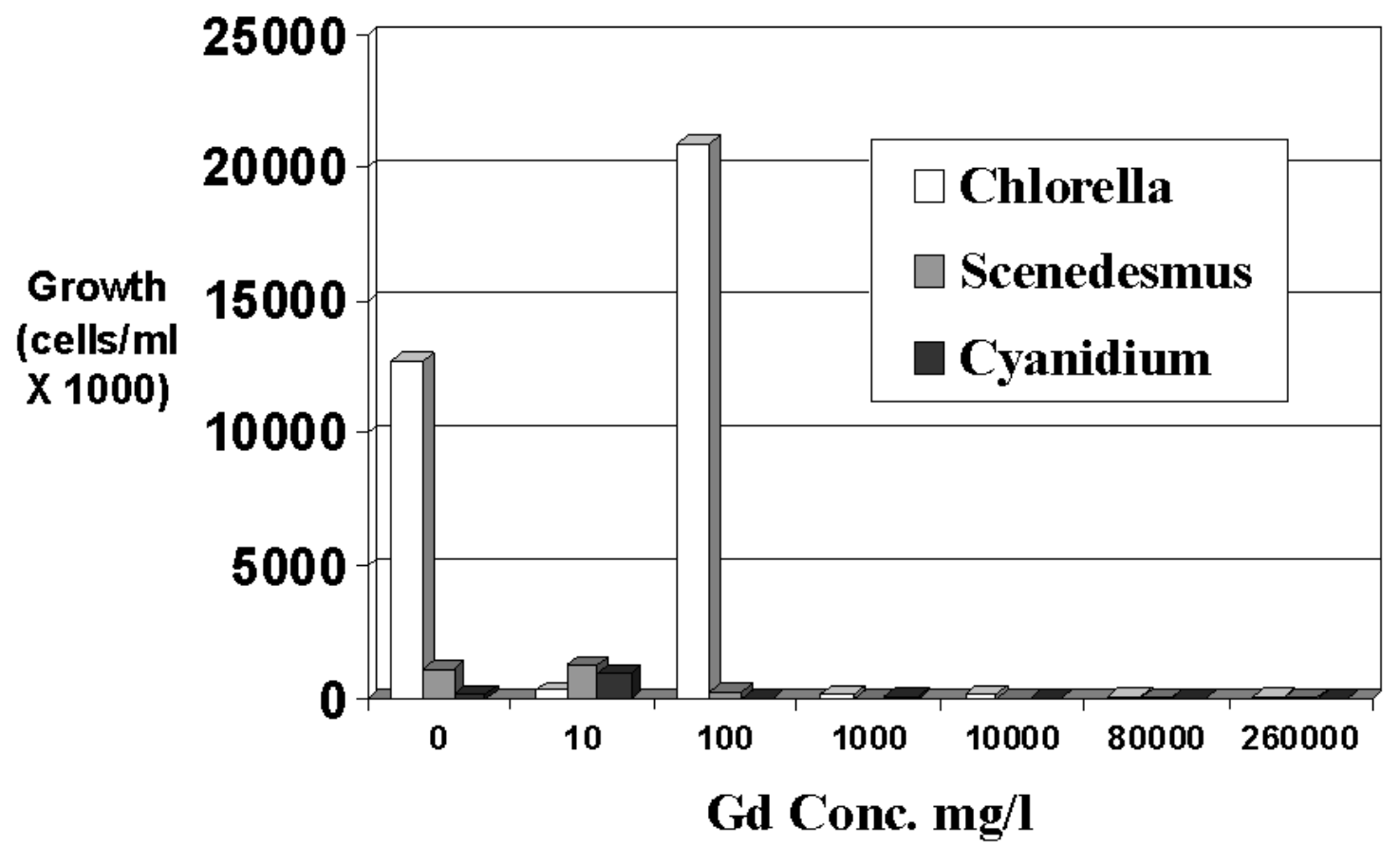

Figure 1. Growth of three species of algae exposed to various concentrations of gadolinium 


\section{Chlorella growth vs $\mathrm{pH}$ and $\mathrm{Gd}$}

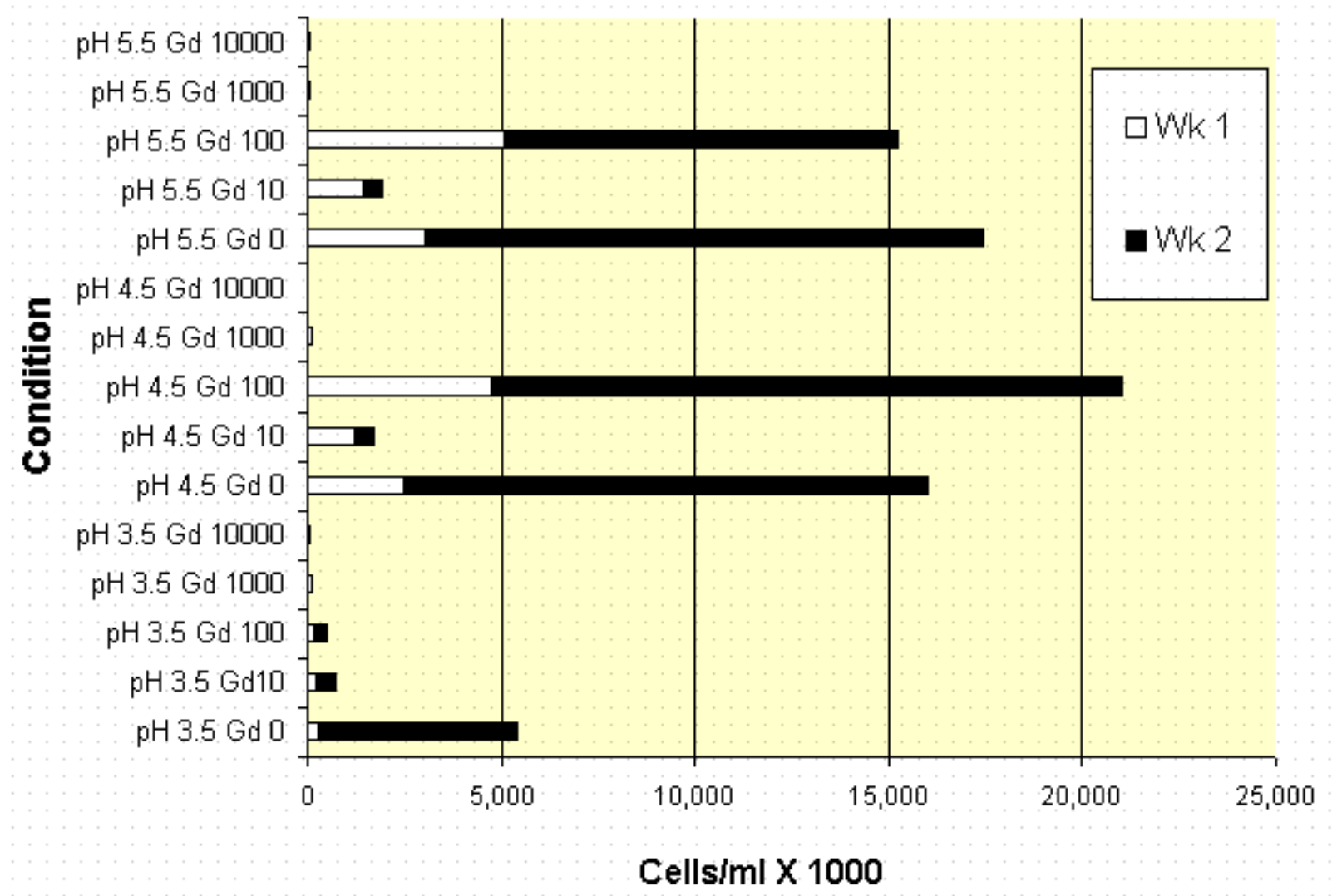

Figure 2. Growth of Chlorella during exposure to various $\mathrm{pH}$ and gadolinium concentrations (mg/l). 
first week. The higher growth in week \#2 compared to week \#1 in the other samples may represent adaptation to the gadolinium in the medium.

Figure 3 shows the growth ofChlorella in modified BB media containing nitrate salts prepared with gadolinium, sodium, potassium and ammonium at concentrations of 0 , $10,100,1000$ and 10000 of the cationic portion of each compound. Gadolinium appears to stimulate growth at $10 \mathrm{mg} / \mathrm{l}$ but results in reduced growth at the higher concentrations. The highest growth occurred with sodium at $100 \mathrm{mg} / \mathrm{l}$. However, at the highest concentration tested $(10,000 \mathrm{mg} / \mathrm{l})$ potassium resulted in the best growth.

Several of the bacteria strains demonstrated growth in the presence of $\mathrm{Gd}$ at concentrations as high as $2000 \mathrm{mg} / \mathrm{l}$. Growth was generally better in nitrate salt solutions with $\mathrm{Na}, \mathrm{K}$ and $\mathrm{NH}_{4}$ as the cation than in nitrate salts with $\mathrm{Gd} \mathrm{NQ}$. Of course, It had been previously demonstrated (Section 3.0) that some viable microbes were present in drums containing Gd concentrations as high as $203,800 \mathrm{mg} / \mathrm{l}$ (Table 2). However these cells did not respond to nutrient enrichment.

Overall, it was concluded that although some microbes can survive at extremely high Gd concentrations, gadolinium is more toxic to algae and bacteria than the other cations tested. 


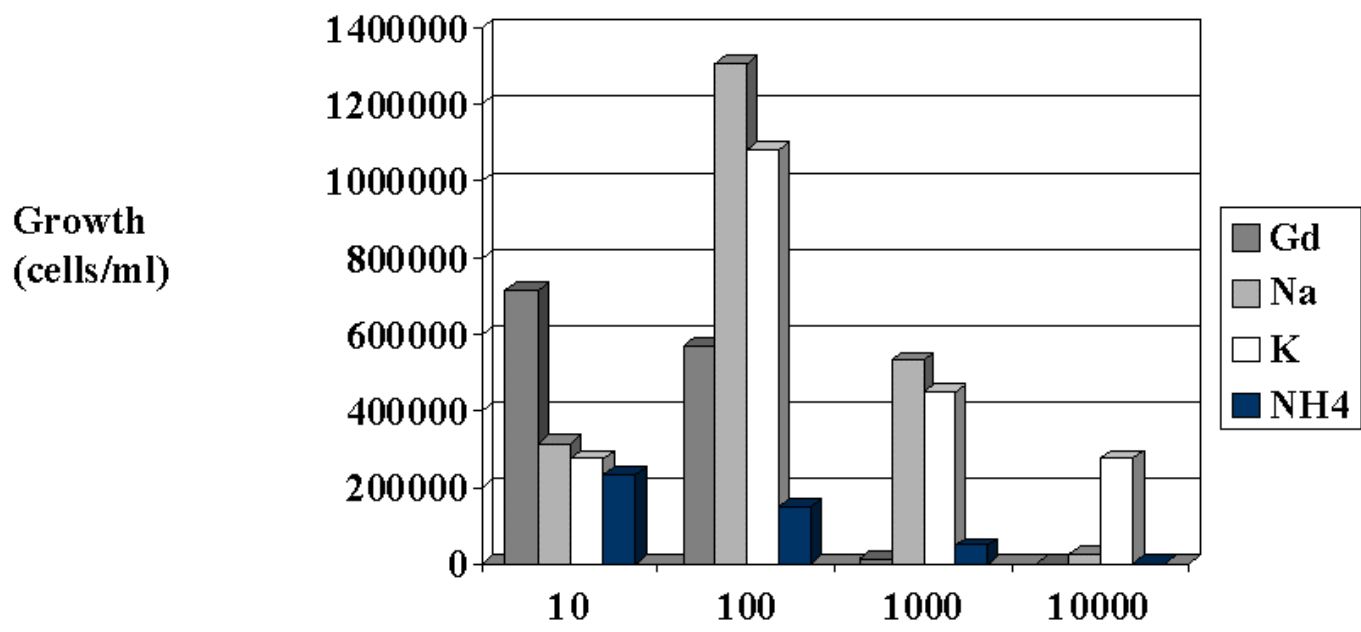

Concentration $(\mathrm{mg} / \mathrm{l})$

Figure 3. Comparative algal growth in four nitrate salt solutions 


\subsection{Precipitation of Gadolinium}

The toxicity experiments (Section 4) clearly demonstrated that Gadolinium is toxic to microorganisms at the higher concentrations present in some of the drums.

Furthermore, it would not be feasible to expect biological processes associated with microorganisms to remove a high percentage of the extremely high gadolinium concentrations (259K ppm maximum, $80 \mathrm{~K} \mathrm{ppm} \mathrm{mean)} \mathrm{present} \mathrm{in} \mathrm{the} \mathrm{drums.} \mathrm{Thus,}$ removal of the gadolinium by precipitation prior to nitrate removal was evaluated. It is well known that soluble Gadolinium salts like nitrate can be very easily precipitated from solution by using alkali metal salts like $\mathrm{PQ}^{-3}, \mathrm{HPO}_{4}{ }^{-2}$, etc., or that of ammonium ions. A general formula for the GdPQ precipitation is as follows:

$$
\begin{aligned}
\mathrm{Gd}\left(\mathrm{NO}_{3}\right)_{3}+ & \mathrm{M}_{3} \mathrm{PO}_{4} \text { (solid or solution) }--->\mathrm{GdPO}_{4} \text { (solid) }+3 \mathrm{MNO}_{3} \text { (sol) } \\
& \text { where } \mathrm{M} \text { can be } \mathrm{Na}^{+1}, \mathrm{~K}^{+1} \text { or } \mathrm{NH}_{4}{ }^{+1}
\end{aligned}
$$

\section{Methods}

Initially, we tested the following reaction:

$\mathrm{Gd}\left(\mathrm{NO}_{3}\right)_{3}$ (aqueous) $+\mathrm{Na}_{3} \mathrm{PO}_{4} \cdot 12 \mathrm{H}_{2} \mathrm{O}$ (solid) -----> $\mathrm{GdPO}_{4}$ (solid) + $3 \mathrm{Na}^{+1}$ (aqueous) $+3 \mathrm{NO}_{3}^{-1}$ (aqueous)

A 13,939 ppm Gd solution as $\mathrm{Gd}\left(\mathrm{NO}_{3}\right)_{3}$ was prepared by adding $2 \mathrm{~g}(4.432 \mathrm{mmol})$ $\mathrm{Gd}\left(\mathrm{NO}_{3}\right)_{3} \cdot 6 \mathrm{H}_{2} \mathrm{O}$ to $50 \mathrm{ml}$ of $\mathrm{DI} \mathrm{H}_{2} \mathrm{O}$ in a $250 \mathrm{ml}$ Erlenmeyer flask.A magnetic stir bar was placed in the flask and $1.6846 \mathrm{~g}(4.432 \mathrm{mmol})$ of sodium phosphate dodecahydrate, a solid, was added to the flask and the solution was stirred for on a magnetic stirrer for 5 min. The Gd (III) phosphate appeared to precipitate out immediately. The supernatant solution was filtered through a Corning 430711 ( $250 \mathrm{ml}, 0.2$ um nylon membrane) system using a vacuum pump. A $10 \mathrm{ml}$ aliquot of the filtrate wasneasured for $\mathrm{Gd}(\mathrm{III})$ using Inductively Coupled Argon Plasma Spectroscopy. This experiment was repeated three times. The third time the experiment was conducted, the precipitate was washed three times with $5 \mathrm{~m} 1$ with DI water to make sure that all the water-soluble nitrates were washed out. It was then placed on an watch glass and dried overnight in a drying oven at $320^{\circ} \mathrm{F}$. The precipitate sample was then submitted to an off-site laboratory (Galbraith Laboratories) for a determination of Karl Fischer Water, determined by coulometric titration and phosphorus using Inductively Coupled Plasma Optical Emission Spectroscopy. This was done to obtain an estimate of the hydrate concentration of the precipitate.

\section{Results and Discussion}

Initial experiments using $\mathrm{NaPO}_{4} \cdot 12 \mathrm{H}_{2} \mathrm{O}$ as the precipitating agent demonstrated that virtually all dissolved gadolinium can be precipitated in a single precipitation step, that takes less than 30 minutes and can be done by a solid or liquid (solution) of $\mathrm{N}_{\mathrm{2O}}$. 
There was no noticeable difference in the use of dry or wet sodium phosphate in the precipitation of Gadolinium as GdPQ. The yield was close to $100 \%$ in both cases. Analyses of the precipitate indicated that it contained $10.43 \%$ phosphorus and $7.58 \%$ $\mathrm{H}_{2} \mathrm{O}$ which corresponds to a compound like $\mathrm{GdPQ} 1 \mathrm{H}_{2} \mathrm{O}$.

Four major concerns associated a Gd precipitation step are discussed below:

1. Can we easily and cost-effectively remove the metal from the drumlt was clearly demonstrated in this study and is generally well known that soluble Gadolinium salts like nitrate can be very easily precipitated from solution by using alkali metal salts like $\mathrm{P}_{4} \hat{\mathrm{O}}$, $\mathrm{HPO}_{4}{ }^{-2}$, etc., or that of ammonium ions.

2. Can the integrity of the heavy water be retained? (i.e. can the step be performed with minimal hydrate formation?) It appears the precipitation step will result in a small loss of heavy water due to hydrate formation within the precipitate. However, that heavy water can be recovered by heating the hydrate to $15 \mathrm{CC}$ and condensing the vapor.

3. Can the gadolinium be recovered in a reusable (salable) form Gadolinium is a rare metal with very unusual properties including unique ferromagnetic characteristics. These properties give the element high market value potential. Gadolinium is presently used in presently used in numerous high-tech products and is a key element in MRI technology. The possible presence of trace levels of radionuclides in the precipitate could make this problematic.

4. Will the remaining solution in the drum, containing less toxic chemicals like $\mathrm{NaN}_{3} \mathrm{O}$ $\mathrm{KNO}_{3}$ or $\mathrm{NH}_{4} \underline{\mathrm{NO}}_{3}$ be amenable to further chemical and biological treatment to result in purified $\mathrm{D}_{2} \mathrm{O}$ ? The complete answer to this question is uncertain at this point and awaits further developmental work. However, the experimental work performed thus far has demonstrated several advantages of utilizing a precipitation step in the process of removing gadolinium from heavy water. Gadolinium is extracted out of the waste drums very easily. The process takes less than 1 hour and results in very little heavy water losses due to hydrate formation. The residual solution containing relatively non-toxic salts like $\mathrm{NaNO}_{3}$ or $\mathrm{KNO} 3$ should be amenable to further purification by biological treatment and possibly by electrochemical treatment. If $\left(\mathrm{NH}_{3} \mathrm{PO}_{4}\right.$ is used as the precipitating agent, then the by-product left in the waste drum will be $\mathrm{N}_{4} \mathrm{NO}_{3}$ for which there is an electrochemical (electrolysis) method documented in the literature (Voortmam, 1993). This precipitating agent would, of course, result in higher losses of heavy water to the precipitate than would be the case with sodium or potassium salts. 


\subsection{Microbial growth and uptake of nitrate}

Studies were performed to assess the ability of selected microbes to remove nitrate from simulated contaminated moderator drum water. It is envisioned that biological nitrate removal, utilizing denitrification by bacteria or uptake by algae during growth would be employed as part of the overall process for removing gadolinium nitrate from the contaminated drums. The low levels of tritium in the drum waters made it impractical to conduct most of the initial nitrate removal studies in the laboratory using actual drum water samples.

\section{Methods}

Nitrate measurements were performed using ion chromatography on samples from each of the three algal experiments described in Section 4.0. The most comprehensive analysis of nitrate removal by algae was in experiment 3 where triplicate flasks of modified BB media were spiked with nitrate salts resulting in concentrations of $\mathrm{Gd}, \mathrm{Na}$, $\mathrm{K}$, and $\mathrm{NH}_{4}$ of $10,100,1000$ and $10000 \mathrm{mg} / \mathrm{l}$. The samples were analyzed for nitrate concentration before and after treatment with algae in whiclEhlorella $(3.61 \mathrm{E}+05$ cells $/ \mathrm{ml}$ ) was inoculated and allowed to grow in $25 \mathrm{ml}$ of Modified BB Media in $50 \mathrm{ml}$ flasks placed in a light programmed environmental chamber (New Brunswick Scientific) for two weeks at $20^{\circ} \mathrm{C}$, with a $12 \mathrm{~h}$ light $\left(200 \mu \mathrm{E}^{-2} \mathrm{~s}^{-1}\right): 12 \mathrm{~h}$ dark illumination regime and $100 \mathrm{rpm}$ rotation. The nitrate concentration in triplicate "control" flasks (treated identically to the flasks containing algae with the exception of the algal inoculation) was also measured.

Strains of denitrifying bacteria were tested for their ability to remove nitrate in the form of $\mathrm{Gd}\left(\mathrm{NO}_{3}\right)_{3}$, and in the possible forms resulting from a precipitation step as described in Section 5.0. $\left(\mathrm{NaNO}_{3}, \mathrm{KNO}_{3}\right.$, or $\mathrm{NH}_{4} \mathrm{NO}_{3}$ ). Following screening tests utilizing various media spiked with $0-2000 \mathrm{mg} / \mathrm{l}$ of the anionic component of the salt solution, the organisms showing the best growth were selected, Samples were incubated overnight and subsequently preserved prior to being tested for nitrate concentration as measured by ion chromatography.

\section{Results and Discussion}

Table 5 shows the results of the nitrate analyses of the samples spiked with four different nitrate salts. Nitrate reduction in response to algal growth was evident in many cases, especially at the lower salt concentrations. However, valid comparisons between algal growth and nitrate removal could not be made for many of the test conditions because of the considerable unexpected variation between the predicted quantities of nitrate, based on media preparation and the nitrate measurements of samples before and after treatment. Thus, additional experiments need to be conducted before firm conclusions can be made regarding comparative nitrate removal 
Table 5. Nitrate Concentrations ( $\mathrm{mg} / \mathrm{l})$ before and after Inoculation and Growth (1week) of Algae (Chlorella) into Modified Bold's Basal Media Containing Various Nitrate Salts

\begin{tabular}{|c|c|c|c|c|}
\hline Media salt composition & $\begin{array}{l}\text { Calculated } \\
\mathrm{NO}_{3} \\
\text { Estimate } \\
\text { before } \\
\text { treatment }\end{array}$ & \begin{tabular}{|l|} 
NO3 \\
Measured \\
before \\
treatment
\end{tabular} & $\begin{array}{l}\text { NO3 } \\
\text { Measured } \\
\text { After } \\
\text { Treatment } \\
\text { with Algae* } \\
\end{array}$ & $\begin{array}{l}\text { NO3 } \\
\text { Measured } \\
\text { after } \\
\text { Treatment } \\
\text { with no algae* }\end{array}$ \\
\hline $10 \mathrm{ppm}$ Gd as GdNO3 & 11.8 & $25.3 \pm 0.8$ & $0.3 \pm 0.4$ & $11.6 \pm 1.1$ \\
\hline 100 ppm Gd as GdNO3 & 118 & $37.4 \pm 1.7$ & $20.9 \pm 4.7$ & $30.8 \pm 14.1$ \\
\hline $1000 \mathrm{ppm}$ Gd as GdNO3 & 1180 & $1098 \pm 20.6$ & $2304 \pm 132$ & $12907 \pm 1040$ \\
\hline $10,000 \mathrm{ppm}$ Gd as GdNO3 & 11800 & $10549 \pm 218$ & $11520 \pm 154$ & $12344 \pm 319$ \\
\hline 10 ppm Na as NaNO3 & 26.95 & $27.4 \pm 0.4$ & $2.8 \pm 4.0$ & $27.3 \pm 0.5$ \\
\hline 100 ppm Na as NaNO3 & 269.5 & $58.4 \pm 20.0$ & $50.1 \pm 11.9$ & $74.9 \pm 1.0$ \\
\hline 1000 ppm Na as NaNO3 & 2695 & $3557 \pm 121$ & $1782 \pm 47$ & $1913 \pm 44$ \\
\hline $10,000 \mathrm{ppm} \mathrm{Na}$ as $\mathrm{NaNO} 3$ & 26950 & $\begin{array}{c}19276 \pm 143 \\
2\end{array}$ & $17567 \pm 2714$ & $21173 \pm 772$ \\
\hline $10 \mathrm{ppm} \mathrm{K}$ as KNO3 & .89 & $3441 \pm 80.0$ & & \\
\hline $100 \mathrm{ppm} \mathrm{K}$ as KNO3 & 158.9 & 20 & 60. & 0.6 \\
\hline 1000 ppm K as KNO3 & 1589 & $1326 \pm 9$ & 1297 & 134 \\
\hline 10,000 ppm $\mathrm{K}$ as KNO3 & 15890 & $\begin{array}{c}16097 \pm 329 \\
1\end{array}$ & $14255 \pm 70$ & $14636 \pm 368$ \\
\hline $10 \mathrm{ppm} \mathrm{NH}_{4}$ & 34.44 & $7.8 \pm 1.8$ & 62.8 & \\
\hline $100 \mathrm{ppm} \mathrm{NH}_{4}$ as $\mathrm{NH}_{4} \mathrm{NO} 3$ & 344.4 & $312.7 \pm 10.8$ & $317.3 \pm 8.6$ & $316.3 \pm 5.0$ \\
\hline 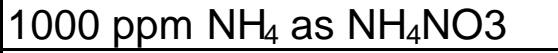 & 3444 & $3266 \pm 242$ & $3258 \pm 37$ & $3197 \pm 25$ \\
\hline $10,000 \mathrm{ppm} \mathrm{NH} \mathrm{NH}_{4}$ as $\mathrm{NH}_{4} \mathrm{NO} 3$ & 34440 & $\begin{array}{c}31289 \pm 144 \\
9\end{array}$ & $39522 \pm 8882$ & $34881 \pm 2416$ \\
\hline
\end{tabular}

${ }^{*}$ Mean and standard deviation of three replicates 
by algae in the presence of various concentrations and anionic components of nitrate salts being considered for use in the heavy water drum purification project.

The results form the tests utilizing denitrifying bacteria are shown in Table 6 . Substantial nitrate reduction occurred with all the nitrate salts evaluated. However, the data in this initial scoping study were insufficient to clearly delineate the best microbial strain or nutrient source to be used in the conceptual process.

Overall, the nitrate removal studies indicated feasibility of substantial nitrate removal by algal uptake and by bacterial denitrification. However, the utilization of either mechanism in the proposed drum purification process requires further refinement. 


\section{Table 6. Nitrate Removal by Denitrifying Bacteria under Various Conditions}

\begin{tabular}{|c|c|c|c|c|c|}
\hline $\begin{array}{l}\text { Samp. } \\
\text { \# }\end{array}$ & $\begin{array}{l}\text { Strain and } \\
\text { Culture Cond. }\end{array}$ & $\begin{array}{l}\text { Cation } \\
\text { Concentration }\end{array}$ & $\begin{array}{l}\text { Initial NO3 Conc. } \\
\text { (mg/l) Calculated }\end{array}$ & $\begin{array}{l}\text { Final NO3 Conc. } \\
\text { (mg/l) Measured }\end{array}$ & $\begin{array}{l}\text { Percent } \\
\text { Removal }\end{array}$ \\
\hline B1 & $\# 1$ ptyg $\mathrm{pH} 6$ & $\mathrm{Na} 0 \mathrm{mg} / \mathrm{l}$ & 0 & 0.1 & 0 \\
\hline B2 & $\# 1$ ptyg $\mathrm{pH} 4$ & $\mathrm{NaO} \mathrm{mg} / \mathrm{l}$ & 0 & 0.1 & 0 \\
\hline B12 & \#1Tol3 pH 4 & $\mathrm{Na} 0 \mathrm{mg} / \mathrm{l}$ & 0 & 0.1 & 0 \\
\hline B13 & \#1Tol3 pH 6 & $\mathrm{Na} 0 \mathrm{mg} / \mathrm{l}$ & 0 & 0.1 & 0 \\
\hline B21 & \#1Tol4 pH 4 & $\mathrm{NaO} \mathrm{mg} / \mathrm{l}$ & 0 & 0.2 & 0 \\
\hline B20 & \#1Tol4 pH 6 & $\mathrm{Na} 0 \mathrm{mg} / \mathrm{l}$ & 0 & 0.4 & 0 \\
\hline B22 & \#1Tol4 pH 4 & $\mathrm{Na} 2 \mathrm{mg} / \mathrm{l}$ & 5.4 & 4.6 & 14.8 \\
\hline B3 & \#1 ptyg pH 6 & $\mathrm{Na} 2 \mathrm{mg} / \mathrm{l}$ & 5.4 & $<0.1$ & $>98.2$ \\
\hline B4 & \#1 ptyg pH 4 & $\mathrm{Na} 2 \mathrm{mg} / \mathrm{l}$ & 5.4 & $<0.1$ & $>98.2$ \\
\hline B7 & \#1 m9c pH 4 & $\mathrm{Na} 2 \mathrm{mg} / \mathrm{l}$ & 5.4 & 0.1 & 98.2 \\
\hline B14 & \#1Tol3 pH 6 & $\mathrm{Na} 2 \mathrm{mg} / \mathrm{l}$ & 5.4 & 4.7 & 13.0 \\
\hline B5 & $\# 1$ ptyg $\mathrm{pH} 4$ & $\mathrm{Na} 20 \mathrm{mg} / \mathrm{l}$ & 54.0 & 7.4 & 86.3 \\
\hline B15 & \#1Tol3 pH 4 & $\mathrm{Na} 20 \mathrm{mg} / \mathrm{l}$ & 54.0 & 8.2 & 84.8 \\
\hline B16 & \#1Tol3 pH 6 & $\mathrm{Na} 20 \mathrm{mg} / \mathrm{l}$ & 54.0 & 55 & 0 \\
\hline B23 & \#1Tol4 pH 6 & $\mathrm{Na} 20 \mathrm{mg} / \mathrm{l}$ & 54.0 & 26 & 51.9 \\
\hline B6 & $\# 1$ ptyg pH 6 & $\mathrm{Na} 200 \mathrm{mg} / \mathrm{l}$ & 540 & 404 & 25.2 \\
\hline B46 & \#1ptyg pH 4 & $\mathrm{Na} 200 \mathrm{mg} / \mathrm{l}$ & 540 & 97 & 82.0 \\
\hline B8 & $\# 1 \mathrm{~m} 9 \mathrm{c} \mathrm{pH} 4$ & $\mathrm{Na} 200 \mathrm{mg} / \mathrm{l}$ & 540 & 269 & 49.8 \\
\hline B10 & $\# 1 \mathrm{~m} 9 \mathrm{c} \mathrm{pH} 4$ & $\mathrm{KO} \mathrm{mg} / \mathrm{l}$ & 0 & 0.1 & 0 \\
\hline B11 & $\# 1 \mathrm{~m} 9 \mathrm{c} \mathrm{pH} 4$ & $\mathrm{KO} \mathrm{mg} / \mathrm{l}$ & 0 & 0.1 & 0 \\
\hline B17 & \#1Tol3 pH 4 & $\mathrm{~K} 2 \mathrm{mg} / \mathrm{l}$ & 3.2 & 1.8 & 43.8 \\
\hline B25 & \#1Tol4 pH 4 & $\mathrm{~K} 2 \mathrm{mg} / \mathrm{l}$ & 3.2 & 9.8 & 0 \\
\hline B9 & $\# 1 \mathrm{~m} 9 \mathrm{c} \mathrm{pH} 4$ & $\mathrm{~K} 20 \mathrm{mg} / \mathrm{l}$ & 31.8 & 17 & 46.5 \\
\hline B18 & \#1Tol3 pH 4 & $\mathrm{~K} 20 \mathrm{mg} / \mathrm{l}$ & 31.8 & 14 & 56.0 \\
\hline B26 & \#1Tol4 pH 4 & $\mathrm{~K} 20 \mathrm{mg} / \mathrm{l}$ & 31.8 & 7.3 & 77.0 \\
\hline B19 & \#1Tol3 pH 4 & $\mathrm{~K} 200 \mathrm{mg} / \mathrm{l}$ & 318 & 266 & 16.4 \\
\hline B27 & \#1Tol4 pH 6 & $\mathrm{NH} 42 \mathrm{mg} / \mathrm{l}$ & 6.9 & 10.3 & 0 \\
\hline B28 & \#1Tol4 pH 6 & $\mathrm{NH} 420 \mathrm{mg} / \mathrm{l}$ & 68.8 & 6.0 & 91.3 \\
\hline B29 & \#1Tol3 pH 6 & $\mathrm{NH} 4200 \mathrm{mg} / \mathrm{l}$ & 688 & 32 & 95.4 \\
\hline B30 & \#1 M9c/ptyg & $\mathrm{Gd} 0 \mathrm{mg} / \mathrm{l}$ & 0 & 10.7 & 0 \\
\hline B33 & \#2 PTYG pH 6 & $\mathrm{Gd} 0 \mathrm{mg} / \mathrm{l}$ & 0 & 10.8 & 0 \\
\hline B39 & $\# 1 \mathrm{~m} 9 \mathrm{c} \mathrm{pH} 6$ & $\mathrm{Gd} 0 \mathrm{mg} / \mathrm{l}$ & 0 & 1.1 & 0 \\
\hline B40 & $\# 1 \mathrm{~m} 9 \mathrm{c} \mathrm{pH} 4$ & $\mathrm{Gd} 0 \mathrm{mg} / \mathrm{l}$ & 0 & 10.8 & 0 \\
\hline B34 & \#2 PTYG pH 6 & $\mathrm{Gd} 1 \mathrm{mg} / \mathrm{l}$ & 1.2 & 10.7 & 0 \\
\hline B35 & \#2 PTYG pH 4 & $\mathrm{Gd} 1 \mathrm{mg} / \mathrm{l}$ & 1.2 & 10.7 & 0 \\
\hline B41 & $\# 1 \mathrm{~m} 9 \mathrm{c} \mathrm{pH} 6$ & $\mathrm{Gd} 10 \mathrm{mg} / \mathrm{l}$ & 11.8 & $<0.1$ & $>99.1$ \\
\hline B31 & \#1 M9c/ptyg? & $\mathrm{Gd} 10 \mathrm{mg} / \mathrm{l}$ & 11.8 & 10.7 & 9.3 \\
\hline B36 & \#2 PTYG pH 6 & Gd $10 \mathrm{mg} / \mathrm{l}$ & 11.8 & 10.5 & 11.0 \\
\hline B42 & $\# 1 \mathrm{~m} 9 \mathrm{c}$ pH 6 & Gd $100 \mathrm{mg} / \mathrm{l}$ & 118 & 10.7 & 90.9 \\
\hline B43 & $\# 1 \mathrm{~m} 9 \mathrm{c} \mathrm{pH} 4$ & Gd $100 \mathrm{mg} / \mathrm{l}$ & 118 & 4 & 96.6 \\
\hline B32 & \#1 M9c/ptyg? & Gd $100 \mathrm{mg} / \mathrm{l}$ & 118 & 29.6 & 25.1 \\
\hline B37 & \#2 PTYG pH 6 & Gd $100 \mathrm{mg} / \mathrm{l}$ & 118 & 3.4 & 97.1 \\
\hline B38 & \#2 PTYG pH 4 & $\mathrm{Gd} 100 \mathrm{mg} / \mathrm{l}$ & 118 & 4.1 & 96.5 \\
\hline B44 & $\# 1 \mathrm{~m} 9 \mathrm{c}$ pH 6 & Gd $1000 \mathrm{mg} / \mathrm{l}$ & 1180 & 101 & 91.4 \\
\hline B45 & $\# 1 \mathrm{~m} 9 \mathrm{c} \mathrm{pH} 4$ & Gd $1000 \mathrm{mg} / \mathrm{l}$ & 1180 & 102 & 91.4 \\
\hline
\end{tabular}




\subsection{Conceptual Process Design}

Based on the experimental results of this study, a novel conceptual process for the purification of heavy water containing large concentrations of gadolinium nitrate has been developed (Figure 4). The process contains the following steps:

1. Chemical precipitation to remove gadolinium from the drum

2. Removal of the anionic precipitating agent (e.g. K) and much of the N@lising electrochemical techniques

3. Complete (nitrate removal (e.g. to ppb level) by the growth and subsequent removal of select microbes

4. Upgrading $\mathrm{D}_{2} \mathrm{O}$ purity as necessary for resale of the purified heavy water

5. Recovery and reprocessing, if necessary, to provide gadolinium for resale as a high value product. 


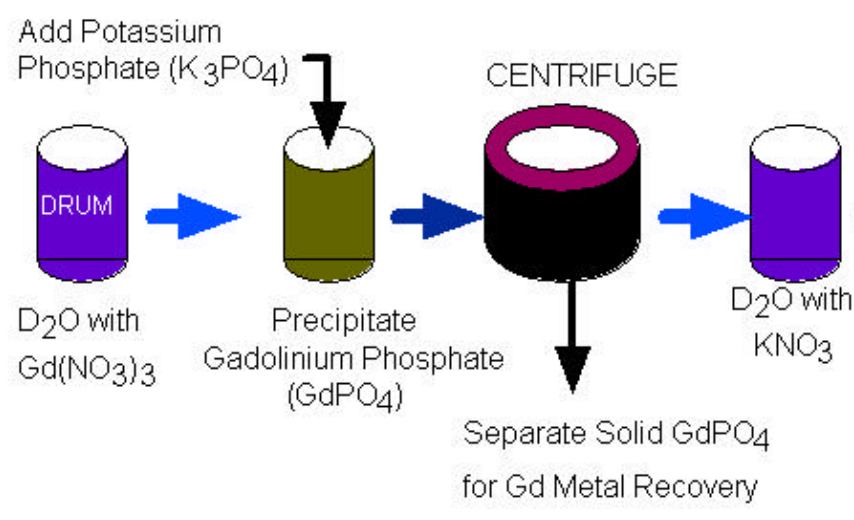

PRECIPITATION AND RECOVERY OF GADOLINIUM

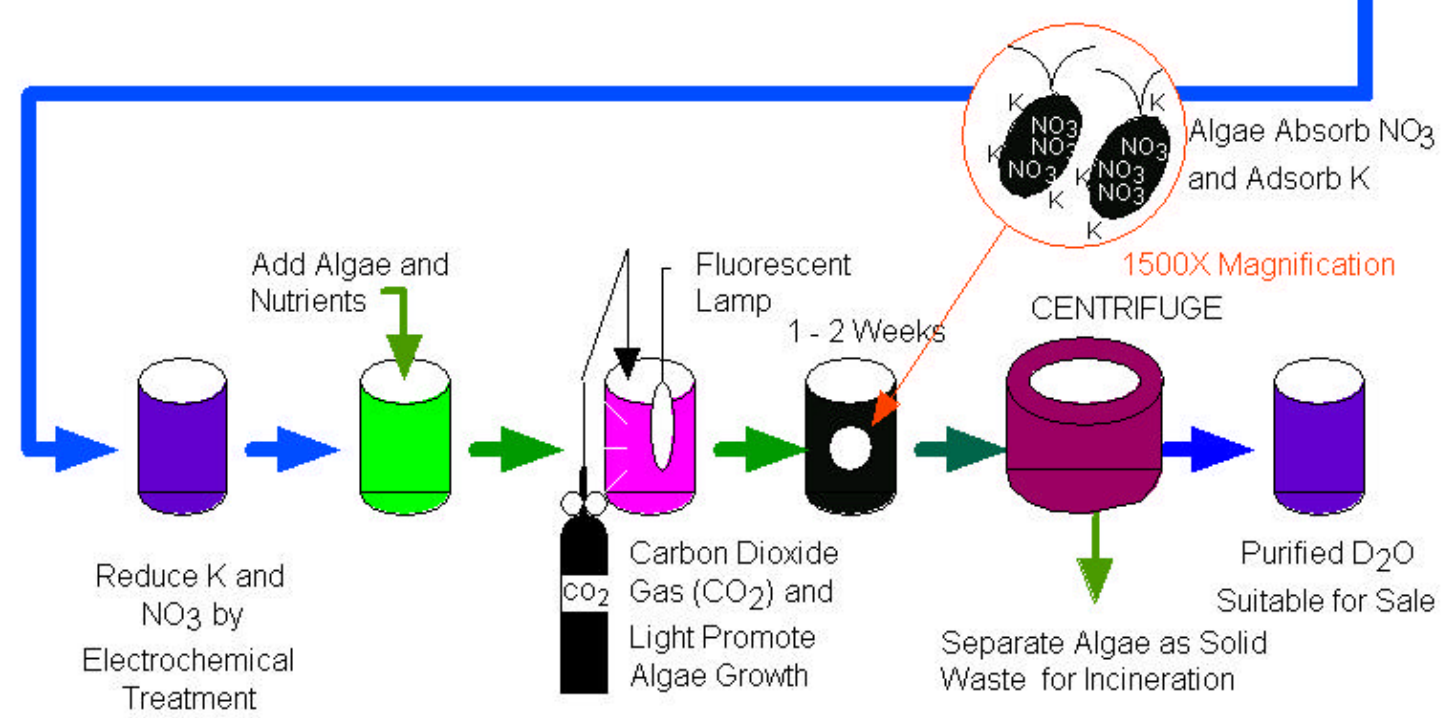

REMOVAL OF NITRATE

Figure 4. Conceptual Process for Purifying Drums of Heavy Water Containing $\mathrm{Gd}\left(\mathrm{NO}_{3}\right)_{3}$ 


\subsection{Proposed Future Work}

The study provided the development of a novel four-step conceptual process for the purification of heavy water containing large concentrations of gadolinium nitrate. The process would provide several key advantages over an ion exchange process. Encouraging results were obtained in the initial proof-of-concept experiments. However, continued development is required in the following areas:

\section{Chemical Precipitation Step:}

It remains to be demonstrated how the gadolinium can be optimally precipitated for the minimization of hydrate formation and processing costs along with the best suitability for further treatment for nitrate removal using actual heavy water with the candidate precipitating agents identified in the study.

\section{Bulk Nitrate Removal Step:}

Although microbiologically induced nitrate removal is deemed an integrapart of the overall nitrate removal process, an inexpensive nitrate removal scheme that would generate very little secondary waste and efficiently reduce the very high nitrate levels remaining after the precipitation step (e.g. thousands of ppm) to levels more amenable to biological removal (e.g. tens to hundreds of ppm). Electrolysis processes appear most promising for this intermediate step in the overall nitrate removal scheme.

\section{Microbiological Nitrate Removal Step:}

It was demonstrated in the study that some strains of algae and bacteria are tolerant to nitrate salt concentrations up to the levels present in the drums. It is also well known and was documented in the study that that some microbes can grow in heavy water concentrations of $>99 \%$ and that microbes can remove nitrate by denitrification and by incorporation of nitrate into biomass. Additional process development work is needed to distinguish the limits of these biological phenomena in relation to the chemical conditions of the subject drums.

\section{Gadolinium Recovery Step:}

The precipitate from the initial step in the process will be GdPQ an extremely rare compound which has unique properties and is the subject of several patents describing novel uses of the compound. For example, Nakagome et. al. 1998) have proposed the use of $\mathrm{GdPO}_{4}$ for use in controlling a novel magnetic refrigerator. Thus, the resultant precipitate from the process could have considerable value as produced. Alternatively, the compound could be chemically treated to recover the gadolinium in a form that is more commonly available commercially. Additional research on gadolinium marketability and recovery methods is required to determine the overall costeffectiveness of the proposed process described in this report. 


\subsection{Literature Cited}

Baumann, E.W. 1980. Preparation and properties of nitrate-deficient gadolinium nitrate solutions. J. Inorg. Nucl. Chem. 42:1705-1709.

Castenholz, R.W. 1982. In: Starr, M.P. (ed.) The Prokaryotes, Springer-Verlag, New York. 236-246.

Gilbert, R. Lepine, L., Laurin, M., Ouellet, L., and R. Gauthier. 1985. Study of complexing reactions causing the depletion of gadolinium ions from the moderator of CANDU-PHW Nuclear Reactors. Can. J. Chem. Eng. 63:978-986.

Nakagome, H., Sdato, A, and Tasuda, S. 1998. Production of working material for a magnetic refrigerator. Patent Application EP223265.

Rodenas, L.G., Prini, R.F., and S.J. Liberman. Radiolysis of aqueous solutions of gadolinium nitrate. J. Radioanalytical and Nuclear Chem. Articles. 139: 277-286.

Tsuji, T. K. Ohki, and Y. Fujita. 1986. Determination of photosynthetic pigment composition in an individual phytoplankton cell in seas and lakes using fluorescence microscopy; properties of the fluorescence emitted from picoplankton cells. Mar. Biol. 93:343-349.

Voortman, W.J., An Evaluation of the Technical Feasibility of Removing Ammonium Nitrate from Aqueous Solutions with Electrolysis', Thesis MScEng, 1993. University of Natal, Pretoria South Africa.

Wilde, E.W. and C.B. Fliermans, 1979. Fluorescence microscopy for algal studies. Trans. Am. Microsc. Soc. 98:96-102.

Wood, A.M., Horan, P.K., Muirhead, K., Phinney, D.A.,Yentch C.M. and J.B. Waterbury. 1985. Discrimination between types of pigments in marine Synechococcus spp. by scanning spectroscopy, epifluorescence microscopy, and flow cytometry. Limnol. Oceanogr. 30:1303-1315. 


\subsection{Acknowledgements}

The authors are grateful to Marilyn Frank, Mary Anne Johnson, Fatina Washburn, Sherold Johnson, Mike Polochko, Robert Ray and Charlie Varner for providing technical assistance on this project. 
February 23, 2000 WSRC-TR-99-00096

\section{APPENDIX}

A-1 
Summary of Algae Experiments:

\begin{tabular}{|l|l|l|l|}
\hline Exp. \# & Scope & Algal Species Used & Table \\
\hline 1 & $\begin{array}{l}\text { Determine potential toxicity of } \\
\text { GdNO } \text { }_{3} \text { to algae by Evaluating } \\
\text { capability of organisms to grow in } \\
\text { GdNO } 3 \text { at concentrations } \\
\text { bracketing the levels in the drums } \\
\text { to be remediated. }\end{array}$ & $\begin{array}{l}\text { Chlorella } \\
\text { Scenedesmus } \\
\text { Closterium } \\
\text { Cyanidium }\end{array}$ & A-1, A-4 \\
\hline 2 & $\begin{array}{l}\text { Determine potential toxicity of } \\
\text { GdNO3 to algae by evaluating } \\
\text { capability of species to grow in } \\
\text { GdNO3 at concentrations deemed } \\
\text { feasible based on Experiment 1. } \\
\text { Results. Also, evaluate influence } \\
\text { of media pH on growth. }\end{array}$ & $\begin{array}{l}\text { Chlorella } \\
\text { Cyanidium } \\
\text { Mastigocladus }\end{array}$ & A-2, A-5 \\
\hline 3 & $\begin{array}{l}\text { 1. Determine comparative toxicity } \\
\text { of GdNO3, NaNO3, KNO3 and } \\
\text { NH4NO3 to algae. } \\
\text { 2. Determine if algae can live in } \\
\text { high nitrate concentrations if } \\
\text { Gd is replaced by other metals } \\
\text { or ammonium. } \\
\text { 3. Determine nitrate uptake by } \\
\text { algae in relation to algal growth } \\
\text { and nitrate compound form at } \\
\text { various concentrations. }\end{array}$ & A-3, A-6 \\
& & \\
\hline
\end{tabular}


Table A-1. Experimental Design for Experiment \#1 showing number of flasks for each treatment

\begin{tabular}{|c|c|c|c|c|c|}
\hline Medium & Chlorella & Scenedesmus & Closterium & Cyanidium & Control \\
\hline BB pH 6.6 (standard formula) & 3 & 3 & 3 & 3 & \\
\hline $\mathrm{BB}$ pH 5.5 & 3 & 3 & & & \\
\hline $\begin{array}{l}\mathrm{BB} \mathrm{pH} 5.5 \mathrm{w} / 10 \mathrm{ppm} \text { Gd as } \\
\mathrm{GdNO}_{3}\end{array}$ & 3 & 3 & & & 1 \\
\hline $\begin{array}{l}\mathrm{BB} \mathrm{pH} 5.5 \mathrm{w} / 100 \text { ppm Gd as } \\
\mathrm{GdNO}_{3}\end{array}$ & 3 & 3 & & & 1 \\
\hline $\begin{array}{l}\mathrm{BB} \mathrm{pH} 5.5 \text { w/ } 1000 \text { ppm Gd as } \\
\mathrm{GdNO}_{3}\end{array}$ & 3 & 3 & & & 1 \\
\hline $\begin{array}{l}\mathrm{BB} \mathrm{pH} 5.5 \mathrm{w} / 10,000 \text { ppm Gd as } \\
\mathrm{GdNO}_{3}\end{array}$ & 3 & 3 & & & 1 \\
\hline $\begin{array}{l}\mathrm{BB} \mathrm{pH} 5.5 \text { w/ 80,000 ppm Gd as } \\
\mathrm{GdNO}_{3}\end{array}$ & 3 & 3 & & & 1 \\
\hline $\begin{array}{l}\mathrm{BB} \text { pH } 5.5 \text { w/ 260,000 ppm Gd } \\
\text { as } \mathrm{GdNO}_{3}\end{array}$ & 3 & 3 & & & 1 \\
\hline BB pH 3.5 (standard formula) & & & 3 & 3 & \\
\hline $\begin{array}{l}\mathrm{BB} \mathrm{pH} 3.5 \text { w/ } 10 \text { ppm Gd as } \\
\mathrm{GdNO}_{3}\end{array}$ & & & 3 & 3 & 1 \\
\hline $\begin{array}{l}\mathrm{BB} \mathrm{pH} 3.5 \mathrm{w} / 100 \mathrm{ppm} \text { Gd as } \\
\mathrm{GdNO}_{3}\end{array}$ & & & 3 & 3 & 1 \\
\hline $\begin{array}{l}\mathrm{BB} \mathrm{pH} 3.5 \text { w/ } 1000 \text { ppm Gd as } \\
\mathrm{GdNO}_{3}\end{array}$ & & & 3 & 3 & 1 \\
\hline $\begin{array}{l}\mathrm{BB} \mathrm{pH} 3.5 \mathrm{w} / 10,000 \mathrm{ppm} \text { Gd as } \\
\mathrm{GdNO}_{3}\end{array}$ & & & 3 & 3 & 1 \\
\hline $\begin{array}{l}\mathrm{BB} \mathrm{pH} 3.5 \mathrm{w} / 80,000 \mathrm{ppm} \text { Gd as } \\
\mathrm{GdNO}_{3}\end{array}$ & & & 3 & 3 & 1 \\
\hline $\begin{array}{l}\mathrm{BB} \text { pH } 3.5 \mathrm{w} / 260,000 \mathrm{ppm} \mathrm{Gd} \\
\text { as } \mathrm{GdNO}_{3}\end{array}$ & & & 3 & 3 & 1 \\
\hline
\end{tabular}


Table A-2. Experimental Design for Experiment 2 showing number of flasks for each treatment

\begin{tabular}{|c|c|c|c|c|c|c|c|}
\hline Medium & $\begin{array}{l}\text { Chlorella } \\
\mathrm{pH} 3.5\end{array}$ & $\begin{array}{l}\text { Chlorella } \\
\mathrm{pH} 4.5\end{array}$ & $\begin{array}{l}\text { Chlorella } \\
\text { pH } 5.5\end{array}$ & $\begin{array}{l}\text { Cyanidium } \\
\text { pH } 3.5\end{array}$ & $\begin{array}{l}\text { Mastigocladus } \\
113 \mathrm{D} \mathrm{pH} 5.5\end{array}$ & $\begin{array}{l}\text { Mastigocladus } \\
\text { M1 pH } 5.5\end{array}$ & $\begin{array}{l}\text { Control } \\
\text { no algae }\end{array}$ \\
\hline BB Std. & 2 & 2 & 2 & 2 & & & $\begin{array}{l}2 \\
(\mathrm{pH} 5.5)\end{array}$ \\
\hline BB w/10ppm Gd & 2 & 2 & 2 & 2 & & & $\begin{array}{l}2 \\
(\mathrm{pH} 5.5)\end{array}$ \\
\hline BB w/ 100 ppm Gd & 2 & 2 & 2 & 2 & & & $\begin{array}{l}2 \\
(\mathrm{pH} 5.5)\end{array}$ \\
\hline BB w/ 1000 ppm Gd & 2 & 2 & 2 & 2 & & & $\begin{array}{l}2 \\
(\mathrm{pH} 5.5)\end{array}$ \\
\hline $\begin{array}{l}\text { BB w/ } 10000 \text { ppm } \\
\text { Gd }\end{array}$ & 2 & 2 & 2 & 2 & & & (pH5.5) \\
\hline $\begin{array}{l}\text { C Std } \\
\text { wo/(NH4) }{ }_{2} S_{4} 4\end{array}$ & & & & 2 & & & 2 \\
\hline $\mathrm{C} \mathrm{w} / 10 \mathrm{ppm} \mathrm{Gd}$ & & & & 2 & & & 2 \\
\hline $\mathrm{C} \mathrm{w/100} \mathrm{ppm} \mathrm{Gd}$ & & & & 2 & & & 2 \\
\hline $\mathrm{C} \mathrm{w} / 1000 \mathrm{ppm} \mathrm{Gd}$ & & & & 2 & & & \\
\hline $\mathrm{C} \mathrm{w/} 10000 \mathrm{ppm} \mathrm{Gd}$ & & & & 2 & & & 2 \\
\hline ND Std pH 5.5 & & & & & 2 & 2 & 2 \\
\hline ND w/ 10 ppm Gd & & & & & 2 & 2 & 2 \\
\hline ND w/ 100 ppm Gd & & & & & 2 & 2 & 2 \\
\hline ND w/ 1000 ppm Gd & & & & & 2 & 2 & 2 \\
\hline ND w/ 10000 ppm Gd & & & & & 2 & 2 & 2 \\
\hline
\end{tabular}


Table A-3 Experimental design and sample numbering scheme for Experiment \#3

\begin{tabular}{|c|c|c|c|}
\hline $\begin{array}{l}\text { Medium } \\
(\mathrm{Ph}=5.0)\end{array}$ & $\mathrm{T}=0$ & $\begin{array}{l}\mathrm{T}=1 \mathrm{wk} \\
\text { Chlorella }\end{array}$ & $\begin{array}{l}\text { T=1 wk } \\
\text { Control } \\
\text { no algae }\end{array}$ \\
\hline $\begin{array}{l}\text { BB w/10 ppm Gd as } \\
\text { GdNO }_{3}\end{array}$ & $\begin{array}{l}\text { X3-1 } \\
\text { X3-2 } \\
\text { X3-3 }\end{array}$ & $\begin{array}{l}X 3-49 \\
X 3-50 \\
X 3-51\end{array}$ & $\begin{array}{l}\text { X3-97 } \\
\text { X3-98 } \\
\text { X3-99 }\end{array}$ \\
\hline $\begin{array}{l}\text { BB w/ } 100 \text { ppm Gd as } \\
\text { GdNO }_{3}\end{array}$ & $\begin{array}{l}X 3-4 \\
X 3-5 \\
\times 3-6\end{array}$ & $\begin{array}{l}X 3-52 \\
X 3-53 \\
X 3-54 \\
\end{array}$ & $\begin{array}{l}X 3-100 \\
X 3-101 \\
X 3-102\end{array}$ \\
\hline $\begin{array}{l}\text { BB w/ } 1000 \mathrm{ppm} \mathrm{Gd} \\
\text { as } \mathrm{GdNO}_{3}\end{array}$ & $\begin{array}{l}X 3-7 \\
X 3-8 \\
X 3-9 \\
\end{array}$ & $\begin{array}{l}X 3-55 \\
X 3-56 \\
X 3-57\end{array}$ & $\begin{array}{l}X 3-103 \\
\text { X3-104 } \\
\text { X3-105 } \\
\end{array}$ \\
\hline $\begin{array}{l}\mathrm{BB} \mathrm{w} / 10000 \mathrm{ppm} \mathrm{Gd} \\
\text { as } \mathrm{GdNO}_{3}\end{array}$ & $\begin{array}{l}X 3-10 \\
X 3-11 \\
X 3-12 \\
\end{array}$ & $\begin{array}{l}X 3-58 \\
X 3-59 \\
X 3-60 \\
\end{array}$ & $\begin{array}{l}X 3-106 \\
\text { X3-107 } \\
\text { X3-108 } \\
\end{array}$ \\
\hline $\begin{array}{l}\text { BB w/10ppm } \mathrm{Na} \text { as } \\
\mathrm{NaNO}_{3}\end{array}$ & $\begin{array}{l}\text { X3-13 } \\
\text { X3-14 } \\
X 3-15\end{array}$ & $\begin{array}{l}X 3-61 \\
X 3-62 \\
X 3-63\end{array}$ & $\begin{array}{l}X 3-109 \\
\text { X3-110 } \\
\text { X3-111 }\end{array}$ \\
\hline $\begin{array}{l}\mathrm{BB} \mathrm{w} / 100 \mathrm{ppm} \mathrm{Na} \text { as } \\
\mathrm{Na} \mathrm{NO}_{3}\end{array}$ & $\begin{array}{l}X 3-16 \\
X 3-17 \\
X 3-18\end{array}$ & $\begin{array}{l}X 3-64 \\
X 3-65 \\
X 3-66\end{array}$ & $\begin{array}{l}X 3-112 \\
X 3-113 \\
X 3-114\end{array}$ \\
\hline $\begin{array}{l}\text { BB w/ } 1000 \text { ppm Na } \\
\text { as } \mathrm{NaNO}_{3}\end{array}$ & $\begin{array}{l}X 3-19 \\
X 3-20 \\
X 3-21\end{array}$ & $\begin{array}{l}X 3-67 \\
X 3-68 \\
X 3-69\end{array}$ & $\begin{array}{l}\mathbf{X} 3-115 \\
X 3-116 \\
X 3-117\end{array}$ \\
\hline $\begin{array}{l}\mathrm{BB} \mathrm{w} / 10000 \mathrm{ppm} \mathrm{Na} \\
\text { as } \mathrm{NaNO}_{3}\end{array}$ & $\begin{array}{l}X 3-22 \\
X 3-23 \\
\text { X3-24 }\end{array}$ & $\begin{array}{l}\text { X3-70 } \\
\text { X3-71 } \\
\text { X3-72 }\end{array}$ & $\begin{array}{l}X 3-118 \\
X 3-119 \\
X 3-120\end{array}$ \\
\hline $\begin{array}{l}\mathrm{BB} \mathrm{w} / 10 \mathrm{ppm} \mathrm{K} \text { as } \\
\mathrm{KNO}_{3}\end{array}$ & $\begin{array}{l}X 3-25 \\
X 3-26 \\
X 3-27\end{array}$ & $\begin{array}{l}X 3-73 \\
\times 3-74 \\
X 3-75\end{array}$ & $\begin{array}{l}X 3-121 \\
X 3-122 \\
X 3-123\end{array}$ \\
\hline $\begin{array}{l}\mathrm{BB} \mathrm{w} / 100 \mathrm{ppm} \mathrm{K} \text { as } \\
\mathrm{KNO}_{3}\end{array}$ & $\begin{array}{l}X 3-28 \\
X 3-29 \\
X 3-30\end{array}$ & $\begin{array}{l}X 3-76 \\
X 3-77 \\
X 3-78\end{array}$ & $\begin{array}{l}X 3-124 \\
X 3-125 \\
X 3-126\end{array}$ \\
\hline $\begin{array}{l}\text { BB w/ } 1000 \text { ppm } \mathrm{K} \text { as } \\
\mathrm{KNO}_{3}\end{array}$ & $\begin{array}{l}\text { X3-31 } \\
\text { X3-32 } \\
\text { X3-33 }\end{array}$ & $\begin{array}{l}X 3-79 \\
X 3-80 \\
X 3-81\end{array}$ & $\begin{array}{l}X 3-127 \\
X 3-128 \\
X 3-129\end{array}$ \\
\hline $\begin{array}{l}\text { BB w/ } 10000 \mathrm{ppm} \mathrm{K} \\
\text { as } \mathrm{KNO}_{3}\end{array}$ & $\begin{array}{l}\text { X3-34 } \\
\text { X3-35 } \\
\text { X3-36 }\end{array}$ & $\begin{array}{l}X 3-82 \\
X 3-83 \\
X 3-84\end{array}$ & $\begin{array}{l}X 3130 \\
X 3-131 \\
\times 3-132\end{array}$ \\
\hline $\begin{array}{l}\mathrm{BB} \mathrm{w/10} \mathrm{ppm} \mathrm{NH} \mathrm{NH}_{4} \text { as } \\
\mathrm{NH}_{4} \mathrm{NO}_{3}\end{array}$ & $\begin{array}{l}X 3-37 \\
X 3-38 \\
X 3-39\end{array}$ & $\begin{array}{l}X 3-85 \\
X 3-86 \\
X 3-87\end{array}$ & $\begin{array}{l}X 3-133 \\
X 3-134 \\
X 3-135\end{array}$ \\
\hline $\begin{array}{l}\text { BB w/ } 100 \mathrm{ppm} \mathrm{NH}_{4} \\
\text { as } \mathrm{NH}_{4} \mathrm{NO}_{3}\end{array}$ & $\begin{array}{l}X 3-40 \\
X 3-41 \\
X 3-42 \\
\end{array}$ & $\begin{array}{l}X 3-88 \\
X 3-89 \\
X 3-90 \\
\end{array}$ & $\begin{array}{l}33-136 \\
X 3-137 \\
X 3-138 \\
\end{array}$ \\
\hline $\begin{array}{l}\text { BB w/ } 1000 \mathrm{ppm} \mathrm{NH}_{4} \\
\text { as } \mathrm{NH}_{4} \mathrm{NO}_{3}\end{array}$ & $\begin{array}{l}X 3-43 \\
X 3-44 \\
X 3-45\end{array}$ & $\begin{array}{l}\text { X3-91 } \\
\text { X3-92 } \\
\text { X3-93 }\end{array}$ & $\begin{array}{l}\mathbf{X} 3-139 \\
X 3-140 \\
X 3-141\end{array}$ \\
\hline $\begin{array}{l}\mathrm{BB} \mathrm{w} / 10000 \mathrm{ppm} \mathrm{NH}_{4} \\
\text { as } \mathrm{NH}_{4} \mathrm{NO}_{3}\end{array}$ & $\begin{array}{l}X 3-46 \\
X 3-47 \\
X 3-48\end{array}$ & $\begin{array}{l}\text { X3-94 } \\
\text { X3-95 } \\
\text { X3-96 }\end{array}$ & $\begin{array}{l}\text { X3-142 } \\
\text { X3-143 } \\
\text { X3-144 }\end{array}$ \\
\hline
\end{tabular}


Table A-4. Experiment \#1 Results: Gd (mg/l), NO3 (mg/l) and algal densities (cells/ml) before during and after a two week incubation period

\begin{tabular}{|c|c|c|c|c|c|c|c|c|c|}
\hline \# & Alga & Medium & $\begin{array}{c}\text { Gd } \\
\text { Before }\end{array}$ & $\begin{array}{c}\text { Gd } \\
\text { After }\end{array}$ & $\begin{array}{l}\text { NO3 calc. } \\
\text { Estimate }\end{array}$ & $\begin{array}{l}\text { NO3 Meas. } \\
\text { Before }\end{array}$ & $\begin{array}{l}\text { NO3 Meas. } \\
\text { After }\end{array}$ & $\begin{array}{l}\text { Algae } \\
\text { After } 1 \text { wk }\end{array}$ & $\begin{array}{l}\text { Algae } \\
\text { After } 2 \text { wk }\end{array}$ \\
\hline 1 & Chlorella & BB Std. (pH 6.6) & $<0.05$ & $<0.05$ & 182.5 & 146 & 22 & $5.66 \mathrm{E}+06$ & $1.41 \mathrm{E}+07$ \\
\hline 2 & Chlorella & BB Std. (pH 6.6) & " & $<0.05$ & 182.5 & " & 25 & & \\
\hline 3 & Chlorella & BB Std. (pH 6.6) & " & $<0.05$ & 182.5 & " & 26 & & \\
\hline 4 & Chlorella & BB $\quad$ pH 5.5 & 0.07 & $<0.05$ & 67 & 150 & 44 & $5.28 \mathrm{E}+06$ & $1.80 \mathrm{E}+07$ \\
\hline 5 & Chlorella & BB $\quad$ pH 5.5 & " & $<0.05$ & 67 & " & 42 & & \\
\hline 6 & Chlorella & BB $\quad$ pH 5.5 & " & $<0.05$ & 67 & " & 36 & & \\
\hline 7 & Chlorella & BB pH $5.5 \mathrm{w} / 10 \mathrm{ppm} \mathrm{Gd*}$ & 11 & 0.097 & 12 & 58.5 & 35 & $2.10 \mathrm{E}+06$ & $2.44 \mathrm{E}+06$ \\
\hline 8 & Chlorella & $\mathrm{BB} \mathrm{pH} 5.5 \mathrm{w} / 10 \mathrm{ppm} \mathrm{Gd}$ & " & lost & 12 & " & missing & & \\
\hline 9 & Chlorella & $\mathrm{BB}$ pH $5.5 \mathrm{w} / 10 \mathrm{ppm} \mathrm{Gd}$ & " & 1 & 12 & " & 33 & & \\
\hline 10 & Chlorella & $\mathrm{BB} \mathrm{pH} 5.5 \mathrm{w} / 100 \mathrm{ppm} \mathrm{Gd}$ & 109 & 7.1 & 118 & 94.1 & 15 & $3.17 \mathrm{E}+06$ & $2.41 \mathrm{E}+07$ \\
\hline 11 & Chlorella & $\mathrm{BB} \mathrm{pH} 5.5 \mathrm{w} / 100 \mathrm{ppm} \mathrm{Gd}$ & " & 7.6 & 118 & " & 15 & & \\
\hline 12 & Chlorella & $\mathrm{BB}$ pH $5.5 \mathrm{w} / 100 \mathrm{ppm} \mathrm{Gd}$ & " & 7.9 & 118 & " & 18 & & \\
\hline 13 & Chlorella & BB pH $5.5 \mathrm{w} / 1000 \mathrm{ppm} \mathrm{Gd}$ & 981 & 1263 & 1184 & 896.6 & 830 & $1.75 \mathrm{E}+05$ & $3.44 \mathrm{E}+05$ \\
\hline 14 & Chlorella & BB pH $5.5 \mathrm{w} / 1000 \mathrm{ppm} \mathrm{Gd}$ & " & 1168 & 1184 & " & 912 & & \\
\hline 15 & Chlorella & BB pH $5.5 \mathrm{w} / 1000 \mathrm{ppm} \mathrm{Gd}$ & " & 854 & 1184 & " & 884 & & \\
\hline 16 & Chlorella & BB pH $5.5 \mathrm{w} / 10,000 \mathrm{ppm} \mathrm{Gd}$ & 9796 & 11,410 & 11843 & 7557.1 & 10828 & $8.51 \mathrm{E}+04$ & $2.56 \mathrm{E}+05$ \\
\hline 17 & Chlorella & BB pH $5.5 \mathrm{w} / 10,000 \mathrm{ppm} \mathrm{Gd}$ & " & 11,610 & 11843 & " & 16123 & & \\
\hline 18 & Chlorella & BB pH $5.5 \mathrm{w} / 10,000 \mathrm{ppm} \mathrm{Gd}$ & " & 11,585 & 11843 & " & 14011 & & \\
\hline 19 & Chlorella & BB pH $5.5 \mathrm{w} / 80,000 \mathrm{ppm} \mathrm{Gd}$ & 77960 & 81,475 & 112,066 & 64851.5 & 91170 & $1.61 \mathrm{E}+05$ & $2.44 \mathrm{E}+05$ \\
\hline 20 & Chlorella & $\mathrm{BB} \mathrm{pH} 5.5 \mathrm{w} / 80,000 \mathrm{ppm} \mathrm{Gd}$ & " & 88,975 & 112,066 & " & 184195 & & \\
\hline 21 & Chlorella & $\mathrm{BB} \mathrm{pH} 5.5 \mathrm{w} / 80,000 \mathrm{ppm} \mathrm{Gd}$ & " & 90,350 & 112,066 & " & 99744 & & \\
\hline 22 & Chlorella & BB pH $5.5 \mathrm{w} / 260,000 \mathrm{ppm} \mathrm{Gd}$ & 200,100 & 457,750 & 364,000 & 123480.2 & $\mathrm{C}$ & $1.43 \mathrm{E}+05$ & $2.20 \mathrm{E}+05$ \\
\hline 23 & Chlorella & BB pH $5.5 \mathrm{w} / 260,000 \mathrm{ppm}$ Gd as GdNO3 & " & 466,000 & 364,000 & " & $\mathrm{C}$ & & \\
\hline 24 & Chlorella & BB pH $5.5 \mathrm{w} / 260,000 \mathrm{ppm} \mathrm{Gd} \mathrm{as} \mathrm{GdNO3}$ & " & 468,500 & 364,000 & " & $\mathrm{C}$ & & \\
\hline 25 & Scenedesmus & BB Std. (pH 6.6) & $<0.05$ & 14.2 & 67 & 146 & 27 & $2.59 \mathrm{E}+05$ & $2.25 \mathrm{E}+06$ \\
\hline 26 & Scenedesmus & BB Std. (pH 6.6) & " & 1.9 & 182.5 & & 31 & & \\
\hline 27 & Scenedesmus & BB Std. (pH 6.6) & " & 0.33 & 182.5 & & 26 & & \\
\hline 28 & Scenedesmus & BB $\quad$ pH 5.5 & 0.07 & 0.14 & 182.5 & 149 & 24 & $1.98 \mathrm{E}+05$ & $1.34+\mathrm{E} 06$ \\
\hline
\end{tabular}


Table A-4. (Cont.)

\begin{tabular}{|c|c|c|c|c|c|c|c|c|c|}
\hline \# & Alga & Medium & $\begin{array}{c}\text { Gd } \\
\text { Before }\end{array}$ & $\begin{array}{c}\text { Gd } \\
\text { After }\end{array}$ & $\begin{array}{l}\text { NO3 calc. } \\
\text { Estimate }\end{array}$ & $\begin{array}{l}\text { NO3 Meas. } \\
\text { Before }\end{array}$ & $\begin{array}{l}\text { NO3 Meas. } \\
\text { After }\end{array}$ & $\begin{array}{l}\text { Algae } \\
\text { After } 1 \text { wk }\end{array}$ & $\begin{array}{l}\text { Algae } \\
\text { After } 2 \text { wk }\end{array}$ \\
\hline 29 & Scenedesmus & BB pH 5.5 & " & $<0.05$ & 182.5 & & 31 & & \\
\hline 30 & Scenedesmus & BB $\mathrm{pH} 5.5$ & " & $<0.05$ & 182.5 & & 35 & & \\
\hline 31 & Scenedesmus & BB pH 5.5 w/ 10 ppm Gd as $\mathrm{GdNO} 3$ & 11 & 1 & 12 & 58 & 25 & $1.31 \mathrm{E}+05$ & $1.41+\mathrm{E} 06$ \\
\hline 32 & Scenedesmus & $\mathrm{BB} \mathrm{pH} 5.5 \mathrm{w} / 10 \mathrm{ppm} \mathrm{Gd}$ as $\mathrm{GdNO} 3$ & " & 64.8 & 12 & & 38 & & \\
\hline 33 & Scenedesmus & BB pH $5.5 \mathrm{w} / 10 \mathrm{ppm}$ Gd as GdNO3 & " & 71.8 & 12 & & 9 & & \\
\hline 34 & Scenedesmus & $\mathrm{BB} \mathrm{pH} 5.5 \mathrm{w} / 100 \mathrm{ppm} \mathrm{Gd}$ as GdNO3 & 109 & 47.2 & 118 & 94 & 41 & $5.70 \mathrm{E}+04$ & $3.43+\mathrm{E} 05$ \\
\hline 35 & Scenedesmus & BB pH $5.5 \mathrm{w} / 100 \mathrm{ppm}$ Gd as GdNO3 & " & 2.5 & 118 & & 31 & & \\
\hline 36 & Scenedesmus & $\mathrm{BB} \mathrm{pH} 5.5 \mathrm{w} / 100 \mathrm{ppm} \mathrm{Gd}$ as GdNO3 & " & 2.5 & 118 & & 58 & & \\
\hline 37 & Scenedesmus & BB pH $5.5 \mathrm{w} / 1000 \mathrm{ppm}$ Gd as GdNO3 & 981 & 819 & 1184 & 886 & 175 & $1.53 \mathrm{E}+04$ & $1.53 \mathrm{E}+04$ \\
\hline 38 & Scenedesmus & BB pH $5.5 \mathrm{w} / 1000 \mathrm{ppm}$ Gd as GdNO3 & " & 922 & 1184 & & 210 & & \\
\hline 39 & Scenedesmus & BB pH $5.5 \mathrm{w} / 1000 \mathrm{ppm}$ Gd as GdNO3 & " & 916 & 1184 & & 94 & & \\
\hline 40 & Scenedesmus & BB pH $5.5 \mathrm{w} / 10,000 \mathrm{ppm}$ Gd as GdNO3 & 9796 & 13,120 & 11843 & 7216 & 16904 & $1.65 \mathrm{E}+04$ & $1.26 \mathrm{E}+04$ \\
\hline 41 & Scenedesmus & $\mathrm{BB} \mathrm{pH} 5.5 \mathrm{w} / 10,000 \mathrm{ppm} \mathrm{Gd}$ as GdNO3 & " & 12,385 & 11843 & & 19787 & & \\
\hline 42 & Scenedesmus & BB pH $5.5 \mathrm{w} / 10,000 \mathrm{ppm}$ Gd as GdNO3 & " & 14,320 & 11843 & & 24116 & & \\
\hline 43 & Scenedesmus & $\mathrm{BB} \mathrm{pH} 5.5 \mathrm{w} / 80,000 \mathrm{ppm} \mathrm{Gd}$ as GdNO3 & 77960 & 96,025 & 112,000 & 64852 & 101665 & $1.56 \mathrm{E}+04$ & $1.81 \mathrm{E}+04$ \\
\hline 44 & Scenedesmus & $\mathrm{BB} \mathrm{pH} 5.5 \mathrm{w} / 80,000 \mathrm{ppm} \mathrm{Gd}$ as GdNO3 & " & 88,825 & 112,000 & & 96332 & & \\
\hline 45 & Scenedesmus & BB pH $5.5 \mathrm{w} / 80,000 \mathrm{ppm}$ Gd as GdNO3 & " & 91,225 & 112,000 & & 102741 & & \\
\hline 46 & Scenedesmus & BB pH $5.5 \mathrm{w} / 260,000 \mathrm{ppm}$ Gd as GdNO3 & 200100 & 285,125 & 364,000 & 123480 & & $7.94 \mathrm{E}+03$ & $1.43 \mathrm{E}+04$ \\
\hline 47 & Scenedesmus & BB pH $5.5 \mathrm{w} / 260,000 \mathrm{ppm}$ Gd as GdNO3 & " & 250,500 & 364,000 & & & & \\
\hline 48 & Scenedesmus & BB pH $5.5 \mathrm{w} / 260,000 \mathrm{ppm}$ Gd as GdNO3 & " & 267,625 & 364,000 & & & & \\
\hline 49 & Closterium & BB std. (pH 6.6) & $<0.05$ & 64.2 & 182.5 & 146 & 29 & & \\
\hline 50 & Closterium & BB Std. (pH 6.6) & " & 0.49 & 182.5 & & 41 & & \\
\hline 51 & Closterium & BB Std. (pH 6.6) & " & 2.2 & 182.5 & & 38 & & \\
\hline 52 & Cyanidium & BB Std. (pH 6.6) & $<0.05$ & 0.2 & 182.5 & 146 & 68 & $7.26 \mathrm{E}+05$ & $7.10 \mathrm{E}+05$ \\
\hline 53 & Cyanidium & BB Std. (pH 6.6) & " & 0.18 & 182.5 & & 83 & & \\
\hline 54 & Cyanidium & BB Std. (pH 6.6) & " & 0.41 & 182.5 & & 75 & & \\
\hline 55 & No Alga & $\mathrm{BB} \mathrm{pH} 5.5 \mathrm{w} / 10 \mathrm{ppm} \mathrm{Gd}$ as $\mathrm{GdNO} 3$ & 11 & 0.74 & 12 & 58 & 75 & & \\
\hline
\end{tabular}


Table A-4. (Cont.)

\begin{tabular}{|c|c|c|c|c|c|c|c|c|c|}
\hline \# & Alga & Medium & $\begin{array}{c}\text { Gd } \\
\text { Before }\end{array}$ & $\begin{array}{c}\text { Gd } \\
\text { After }\end{array}$ & $\begin{array}{l}\text { NO3 calc. } \\
\text { Estimate }\end{array}$ & $\begin{array}{l}\text { NO3 Meas. } \\
\text { Before }\end{array}$ & $\begin{array}{l}\text { NO3 Meas. } \\
\text { After }\end{array}$ & $\begin{array}{l}\text { Algae } \\
\text { After } 1 \text { wk }\end{array}$ & $\begin{array}{l}\text { Algae } \\
\text { After } 2 \text { wk }\end{array}$ \\
\hline 56 & No Alga & BB pH $5.5 \mathrm{w} / 100 \mathrm{ppm}$ Gd as GdNO3 & 109 & 10 & 118 & 94 & 97 & & \\
\hline 57 & No Alga & BB pH $5.5 \mathrm{w} / 1000 \mathrm{ppm}$ Gd as GdNO3 & 981 & 884 & 1184 & 886 & 859 & & \\
\hline 58 & No Alga & BB pH $5.5 \mathrm{w} / 10,000 \mathrm{ppm}$ Gd as GdNO3 & 9796 & 13,280 & 11843 & 7216 & 14959 & & \\
\hline 59 & No Alga & BB pH $5.5 \mathrm{w} / 80,000 \mathrm{ppm}$ Gd as GdNO3 & 77960 & 100,975 & 112,000 & 64851 & 61833 & & \\
\hline 60 & No Alga & BB pH $5.5 \mathrm{w} / 260,000 \mathrm{ppm}$ Gd as GdNO3 & 200100 & 291,125 & 364,000 & 123480 & C & & \\
\hline 61 & Closterium & BB $\mathrm{pH} 3.5$ & $<0.05$ & 2 & 182.5 & 150 & 32 & & \\
\hline 62 & Closterium & BB $\mathrm{pH} 3.5$ & " & 120 & 182.5 & & 34 & & \\
\hline 63 & Closterium & BB $\mathrm{pH} 3.5$ & " & 6.2 & 182.5 & & 28 & & \\
\hline 64 & Closterium & BB pH $3.5 \mathrm{w} / 10 \mathrm{ppm}$ Gd as GdNO3 & 5 & 4.8 & 12 & 59 & 36 & & \\
\hline 65 & Closterium & BB pH $3.5 \mathrm{w} / 10 \mathrm{ppm}$ Gd as GdNO3 & " & 3.3 & 12 & & 17 & & \\
\hline 66 & Closterium & BB $\mathrm{pH} 3.5 \mathrm{w} / 10 \mathrm{ppm}$ Gd as GdNO3 & " & 2.3 & 12 & & 18 & & \\
\hline 67 & Closterium & BB pH $3.5 \mathrm{w} / 100 \mathrm{ppm}$ Gd as GdNO3 & 98 & 11 & 118 & 94 & 176 & & \\
\hline 68 & Closterium & $\mathrm{BB} \mathrm{pH} 3.5 \mathrm{w} / 100 \mathrm{ppm} \mathrm{Gd}$ as GdNO3 & " & 9.7 & 118 & & 229 & & \\
\hline 69 & Closterium & $\mathrm{BB} \mathrm{pH} 3.5 \mathrm{w} / 100 \mathrm{ppm}$ Gd as $\mathrm{GdNO} 3$ & " & 10 & 118 & & 140 & & \\
\hline 70 & Closterium & BB pH $3.5 \mathrm{w} / 1000 \mathrm{ppm}$ Gd as GdNO3 & 1003 & 1003 & 1184 & 896 & 1609 & & \\
\hline 71 & Closterium & BB pH $3.5 \mathrm{w} / 1000 \mathrm{ppm}$ Gd as GdNO3 & " & 1039 & 1184 & & 1244 & & \\
\hline 72 & Closterium & $\mathrm{BB} \mathrm{pH} 3.5 \mathrm{w} / 1000 \mathrm{ppm} \mathrm{Gd}$ as $\mathrm{GdNO} 3$ & " & 1079 & 1184 & & 1988 & & \\
\hline 73 & Closterium & $\mathrm{BB} \mathrm{pH} 3.5 \mathrm{w} / 10,000 \mathrm{ppm} \mathrm{Gd}$ as $\mathrm{GdNO} 3$ & 9872 & 15425 & 11843 & 7557 & 20504 & & \\
\hline 74 & Closterium & $\mathrm{BB} \mathrm{pH} 3.5 \mathrm{w} / 10,000 \mathrm{ppm} \mathrm{Gd}$ as $\mathrm{GdNO}_{3}$ & " & 17535 & 11843 & & 19053 & & \\
\hline 75 & Closterium & BB pH $3.5 \mathrm{w} / 10,000 \mathrm{ppm}$ Gd as GdNO3 & " & 15020 & 11843 & & 17622 & & \\
\hline 76 & Closterium & BB pH $3.5 \mathrm{w} / 80,000 \mathrm{ppm}$ Gd as GdNO3 & 70840 & 107800 & 112,000 & 50169 & 46505 & & \\
\hline 77 & Closterium & BB pH $3.5 \mathrm{w} / 80,000 \mathrm{ppm}$ Gd as GdNO3 & " & 116375 & 112,000 & & & & \\
\hline 78 & Closterium & BB pH $3.5 \mathrm{w} / 80,000 \mathrm{ppm}$ Gd as GdNO3 & " & 93450 & 112,000 & & & & \\
\hline 79 & Closterium & $\mathrm{BB} \mathrm{pH} 3.5 \mathrm{w} / 260,000 \mathrm{ppm} \mathrm{Gd}$ as GdNO3 & 197900 & 281000 & 364,000 & 106182 & C & & \\
\hline 80 & Closterium & BB pH $3.5 \mathrm{w} / 260,000 \mathrm{ppm}$ Gd as GdNO3 & " & 274125 & 364,000 & & C & & \\
\hline 81 & Closterium & BB pH $3.5 \mathrm{w} / 260,000 \mathrm{ppm}$ Gd as GdNO3 & " & 354250 & 364,000 & & & & \\
\hline
\end{tabular}


Table A-4. (Cont.)

\begin{tabular}{|c|c|c|c|c|c|c|c|c|c|}
\hline \# & Alga & Medium & $\begin{array}{c}\text { Gd } \\
\text { Before }\end{array}$ & $\begin{array}{c}\text { Gd } \\
\text { After }\end{array}$ & \begin{tabular}{|l|} 
NO3 calc. \\
Estimate \\
\end{tabular} & NO3 Meas. Before & \begin{tabular}{|l|} 
NO3 Meas. \\
After
\end{tabular} & \begin{tabular}{|l|} 
Algae \\
After 1 wk \\
\end{tabular} & \begin{tabular}{|l|l|} 
Algae & \\
After $\quad 2$ wk
\end{tabular} \\
\hline 82 & Cyanidium & BB $\quad \mathrm{pH} 3.5$ & $<0.05$ & 1.8 & 182.5 & 150 & 186 & $1.17 \mathrm{E}+06$ & $1.37 \mathrm{E}+06$ \\
\hline 83 & Cyanidium & BB pH 3.5 & " & 2.8 & 182.5 & & 177 & & \\
\hline 84 & Cyanidium & BB $\quad$ pH 3.5 & " & 11.1 & 182.5 & & 160 & & \\
\hline 85 & Cyanidium & BB pH 3.5 w/ 10 ppm Gd as GdNO3 & 5 & 3 & 12 & 59 & 16 & $6.46 \mathrm{E}+05$ & $1.59 \mathrm{E}+06$ \\
\hline 86 & Cyanidium & BB pH $3.5 \mathrm{w} / 10 \mathrm{ppm}$ Gd as $\mathrm{GdNO}_{3}$ & & 2.9 & 12 & & 45 & & \\
\hline 87 & Cyanidium & BB pH $3.5 \mathrm{w} / 10 \mathrm{ppm}$ Gd as GdNO3 & " & 2.7 & 12 & & 17 & & \\
\hline 88 & Cyanidium & BB pH 3.5 w/ 100 ppm Gd as GdNO3 & 98 & 4.6 & 118 & 94 & 140 & $6.61 \mathrm{E}+05$ & $5.20 \mathrm{E}+05$ \\
\hline 89 & Cyanidium & $\mathrm{BB} \mathrm{pH} 3.5 \mathrm{w} / 100 \mathrm{ppm} \mathrm{Gd}$ as $\mathrm{GdNO} 3$ & " & 4.9 & 118 & & 119 & & \\
\hline 90 & Cyanidium & BB pH $3.5 \mathrm{w} / 100 \mathrm{ppm} \mathrm{Gd}$ as $\mathrm{GdNO} 3$ & " & 4.5 & 118 & & 222 & & \\
\hline 91 & Cyanidium & $\mathrm{BB} \mathrm{pH} 3.5 \mathrm{w} / 1000 \mathrm{ppm}$ Gd as $\mathrm{GdNO} 3$ & 1003 & 10.57 & 1184 & 897 & 1780 & $5.83 \mathrm{E}+05$ & $6.73 \mathrm{E}+05$ \\
\hline 92 & Cyanidium & $\mathrm{BB} \mathrm{pH} 3.5 \mathrm{w} / 1000 \mathrm{ppm} \mathrm{Gd}$ as $\mathrm{GdNO} 3$ & " & 976 & 1184 & & 1722 & & \\
\hline 93 & Cyanidium & $\mathrm{BB}$ pH $3.5 \mathrm{w} / 1000 \mathrm{ppm} \mathrm{Gd}$ as $\mathrm{GdNO} 3$ & " & 908 & 1184 & & 1688 & & \\
\hline 94 & Cyanidium & BB pH $3.5 \mathrm{w} / 10,000 \mathrm{ppm}$ Gd as GdNO3 & 9872 & 13495 & 11843 & 7557 & 16187 & $4.16 \mathrm{E}+05$ & $4.03 E+05$ \\
\hline 95 & Cyanidium & BB pH $3.5 \mathrm{w} / 10,000 \mathrm{ppm}$ Gd as GdNO3 & " & 13815 & 11843 & & 15346 & & \\
\hline 96 & Cyanidium & $\mathrm{BB} \mathrm{pH} 3.5 \mathrm{w} / 10,000 \mathrm{ppm}$ Gd as GdNO3 & " & 13250 & 11843 & & 15802 & & \\
\hline 97 & Cyanidium & $\mathrm{BB} \mathrm{pH} 3.5 \mathrm{w} / 80,000 \mathrm{ppm} \mathrm{Gd}$ as GdNO3 & 70840 & 102875 & 112,000 & 50169 & 46505 & $1.91 \mathrm{E}+05$ & $1.73 \mathrm{E}+05$ \\
\hline 98 & Cyanidium & BB pH $3.5 \mathrm{w} / 80,000 \mathrm{ppm}$ Gd as GdNO3 & " & 90975 & 112,000 & & c & & \\
\hline 99 & Cyanidium & BB pH $3.5 \mathrm{w} / 80,000 \mathrm{ppm}$ Gd as GdNO3 & " & 94200 & 112,000 & & C & & \\
\hline 100 & Cyanidium & BB pH $3.5 \mathrm{w} / 260,000 \mathrm{ppm}$ Gd as GdNO3 & 197900 & 340625 & 364,000 & 106183 & 98822 & $1.82 \mathrm{E}+05$ & $1.63 \mathrm{E}+05$ \\
\hline 101 & Cyanidium & BB pH $3.5 \mathrm{w} / 260,000 \mathrm{ppm}$ Gd as GdNO3 & " & 331,000 & 364,000 & & c & & \\
\hline 102 & Cyanidium & BB pH $3.5 \mathrm{w} / 260,000 \mathrm{ppm}$ Gd as GdNO3 & " & 299,500 & 364,000 & & C & & \\
\hline 103 & No Alga & $\mathrm{BB} \mathrm{pH} 3.5 \mathrm{w} / 10 \mathrm{ppm} \mathrm{Gd}$ as $\mathrm{GdNO} 3$ & 5 & 139 & 12 & 59 & 52 & & \\
\hline 104 & No Alga & BB pH $3.5 \mathrm{w} / 100 \mathrm{ppm}$ Gd as $\mathrm{GdNO} 3$ & 98 & 9.5 & 118 & 94 & 87 & & \\
\hline 105 & No Alga & BB pH $3.5 \mathrm{w} / 1000$ ppm Gd as $\mathrm{GdNO}_{3}$ & 1003 & 795 & 1184 & 897 & 1042 & & \\
\hline 106 & No Alga & BB pH $3.5 \mathrm{w} / 10,000 \mathrm{ppm}$ Gd as GdNO3 & 9872 & 12,940 & 11843 & 7557 & 7391 & & \\
\hline 107 & No Alga & BB pH $3.5 \mathrm{w} / 80,000 \mathrm{ppm}$ Gd as GdNO3 & 70840 & 100,500 & 112,000 & 50169 & 46505 & & \\
\hline 108 & No Alga & $\mathrm{BB} \mathrm{pH} 3.5 \mathrm{w} / 260,000 \mathrm{ppm} \mathrm{Gd}$ as $\mathrm{GdNO} 3$ & 197900 & 299,125 & 364,000 & 106182 & C & & \\
\hline
\end{tabular}

Note: $c=$ cancelled By D-Area chemist because results appeared erroneous 


\section{Table A-5 Experiment \#2 Results}

\begin{tabular}{|c|c|c|c|c|c|c|c|c|c|c|}
\hline \# & Alga & Medium & $\begin{array}{c}\text { Gd } \\
(\mathrm{mg} / \mathrm{l}) \\
\text { Before }\end{array}$ & $\begin{array}{c}\mathrm{Gd} \\
(\mathrm{md} / \mathrm{l}) \\
\text { After }\end{array}$ & $\begin{array}{l}\text { NO3 } \\
\text { (mg/l) } \\
\text { Est. }\end{array}$ & $\begin{array}{c}\text { NO3 } \\
(\mathrm{mg} / \mathrm{l}) \\
\text { Measured } \\
\text { Before }\end{array}$ & $\begin{array}{c}\text { NO3 } \\
\text { (mg/l) } \\
\text { Measured } \\
\text { After }\end{array}$ & $\begin{array}{c}\text { Algae } \\
\text { (cells/ml) } \\
\text { Inoculation }\end{array}$ & $\begin{array}{l}\text { Algae } \\
\text { (cells/ml) } \\
\text { After 1 wk }\end{array}$ & $\begin{array}{l}\text { Algae } \\
\text { (cells/ml) } \\
\text { After 2 wk }\end{array}$ \\
\hline 1 & Chlo & BB Std. $\mathrm{pH} 3.5$ & & cancel & 182.5 & & 90.9 & 131,020 & 464,496 & $7,472,649$ \\
\hline 2 & Chlo & BB Std. $\mathrm{pH} 3.5$ & & 0.18 & 182.5 & & 76.4 & 203,719 & 461,950 & $3,841,327$ \\
\hline 21 & Chlo & $\mathrm{BB} \mathrm{pH} 3.5 \mathrm{w} / 10 \mathrm{ppm} \mathrm{Gd}$ & & 2.8 & 11.8 & & 5.6 & 202,715 & 245,562 & $1,289,438$ \\
\hline 22 & Chlo & BB pH $3.5 \mathrm{w} / 10 \mathrm{ppm} \mathrm{Gd}$ & & 2.8 & 11.8 & & 5.4 & 218,849 & 576,032 & 677,501 \\
\hline 41 & Chlo & $\mathrm{BB} \quad \mathrm{pH} 3.5 \mathrm{w} / 100 \mathrm{ppm} \mathrm{Gd}$ & & 2.6 & 118.4 & & 98.8 & 170,724 & 279,620 & 606,941 \\
\hline 42 & Chlo & $\mathrm{BB} \mathrm{pH} 3.5 \mathrm{w} / 100 \mathrm{ppm} \mathrm{Gd}$ & & 2.9 & 118.4 & & 99.6 & 172,852 & 373,191 & 836,953 \\
\hline 61 & Chlo & $\mathrm{BB} \mathrm{pH} 3.5 \mathrm{w} / 1000 \mathrm{ppm} \mathrm{Gd}$ & & 801 & $1,184.0$ & & 876.8 & 230,413 & 306,812 & 367,045 \\
\hline 62 & Chlo & BB pH $3.5 \mathrm{w} / 1000 \mathrm{ppm} \mathrm{Gd}$ & & 956 & $1,184.0$ & & 985.3 & 233,785 & 331,404 & 356,508 \\
\hline 81 & Chlo & $\mathrm{BB} \mathrm{pH} 3.5 \mathrm{w} / 10,000 \mathrm{ppm} \mathrm{Gd}$ & & 13,472 & 11,843 & & $9,314.4$ & 213,866 & 222,631 & 306,132 \\
\hline 82 & Chlo & $\mathrm{BB} \mathrm{pH} 3.5 \mathrm{w} / 10,000 \mathrm{ppm} \mathrm{Gd}$ & & 13,020 & 11,843 & & $9,139.9$ & 209,183 & 312,993 & 333,057 \\
\hline 3 & Chlo & BB std. $\mathrm{pH} 4.5$ & & 0.16 & 182.5 & & 3.0 & 167,355 & $1,956,857$ & $10,475,503$ \\
\hline 4 & Chlo & BB Std. pH 4.5 & & 0.09 & 182.5 & & 3.1 & 219,930 & $3,351,990$ & $22,050,441$ \\
\hline 23 & Chlo & BB pH $4.5 \mathrm{w} / 10 \mathrm{ppm} \mathrm{Gd}$ & & 1.5 & 11.8 & & 10.0 & 249,838 & $1,314,949$ & $1,623,494$ \\
\hline 24 & Chlo & $\mathrm{BB} \mathrm{pH} 4.5 \mathrm{w} / 10 \mathrm{ppm} \mathrm{Gd}$ & & 1.5 & 11.8 & & 3.8 & 213,345 & $1,617,810$ & $2,368,380$ \\
\hline 43 & Chlo & $\mathrm{BB} \mathrm{pH} 4.5 \mathrm{w} / 100 \mathrm{ppm} \mathrm{Gd}$ & & 5.5 & 118.4 & & 7.2 & 244,951 & $5,922,118$ & $18,760,376$ \\
\hline 44 & Chlo & $\mathrm{BB} \mathrm{pH} \quad 4.5 \mathrm{w} / 100 \mathrm{ppm} \mathrm{Gd}$ & & 6.2 & 118.4 & & 1.2 & 282,330 & $4,056,899$ & $23,887,978$ \\
\hline 63 & Chlo & BB pH $4.5 \mathrm{w} / 1000 \mathrm{ppm} \mathrm{Gd}$ & & 948 & $1,184.0$ & & 932.3 & 257,363 & 371,435 & 342,148 \\
\hline 64 & Chlo & BB pH $4.5 \mathrm{w} / 1000 \mathrm{ppm} \mathrm{Gd}$ & & 886 & $1,184.0$ & & 942.9 & 237,672 & 352,995 & 384,958 \\
\hline 83 & Chlo & $\mathrm{BB} \mathrm{pH} 4.5 \mathrm{w} / 10,000 \mathrm{ppm} \mathrm{Gd}$ & & 13,216 & 11,843 & & $8,275.7$ & 238,257 & 318,457 & 359,142 \\
\hline 84 & Chlo & $\mathrm{BB} \mathrm{pH} 4.5 \mathrm{w} / 10,000 \mathrm{ppm} \mathrm{Gd}$ & & 12,220 & 11,843 & & $8,721.0$ & 246,784 & 276,308 & 320,798 \\
\hline 5 & Chlo & BB Std. pH 5.5 & & $<0.05$ & 182.5 & & 2.8 & 211,784 & $4,701,760$ & $14,035,281$ \\
\hline 6 & Chlo & BB Std. pH 5.5 & & 0.05 & 182.5 & & 2.9 & 157,667 & $1,717,834$ & $21,315,427$ \\
\hline 25 & Chlo & BB $\mathrm{pH} 5.5 \mathrm{w} / 10 \mathrm{ppm} \mathrm{Gd}$ & & 1.1 & 11.8 & & 3.4 & 160,399 & $1,871,776$ & $2,110,542$ \\
\hline 26 & Chlo & BB pH $5.5 \mathrm{w} / 10 \mathrm{ppm} \mathrm{Gd}$ & & 1 & 11.8 & & 4.9 & 176,498 & $1,338,776$ & $2,221,623$ \\
\hline 45 & Chlo & $\mathrm{BB} \mathrm{pH} 5.5 \mathrm{w} / 100 \mathrm{ppm} \mathrm{Gd}$ & & 8.4 & 118.4 & & 1.2 & 312,213 & $5,908,118$ & $13,482,608$ \\
\hline 46 & Chlo & BB pH $5.5 \mathrm{w} / 100 \mathrm{ppm} \mathrm{Gd}$ & & cancel & 118.4 & & ND & 232,661 & $4,783,429$ & $17,598,352$ \\
\hline 65 & Chlo & BB pH $5.5 \mathrm{w} / 1000 \mathrm{ppm} \mathrm{Gd}$ & & 874 & $1,184.0$ & & $1,026.6$ & 278,315 & 262,471 & 353,873 \\
\hline 66 & Chlo & BB pH 5.5w/1000 ppm Gd & & 901 & $1,184.0$ & & 959.6 & 229,851 & 316,115 & 411,451 \\
\hline 85 & Chlo & BB $\mathrm{pH} 5.5 \mathrm{w} / 10,000 \mathrm{ppm} \mathrm{Gd}$ & & 13,002 & 11,843 & & $7,361.6$ & 252,282 & 225,917 & 352,995 \\
\hline 86 & Chlo & BB $\mathrm{pH} 5.5 \mathrm{w} / 10,000 \mathrm{ppm} \mathrm{Gd}$ & & 12,710 & 11,843 & & $8,532.6$ & 215,947 & 271,625 & 344,627 \\
\hline 9 & none & BB pH 5.5 Std & 0.08 & 0.23 & 182.5 & 25.0 & 135.9 & & & \\
\hline 10 & none & BB pH 5.5 Std & & $<0.05$ & 182.5 & & 138.3 & & & \\
\hline 29 & none & BB pH 5.5 w/10 ppm Gd & 9.5 & 0.99 & 11.8 & 1.5 & 10.8 & & & \\
\hline 30 & none & BB pH 5.5 w/10 ppm Gd & & 0.92 & 11.8 & & 11.7 & & & \\
\hline 49 & none & $\mathrm{BB} \mathrm{pH} 5.5 \mathrm{w} / 100 \mathrm{ppm} \mathrm{Gd}$ & 91.7 & 2.1 & 118.4 & 17.0 & 101.6 & & & \\
\hline 50 & none & BB pH $5.5 \mathrm{w} / 100 \mathrm{ppm} \mathrm{Gd}$ & & 176 & 118.4 & & 99.1 & & & \\
\hline 69 & none & $\mathrm{BB} \mathrm{pH} 5.5 \mathrm{w} / 1000 \mathrm{ppm} \mathrm{Gd}$ & 1005 & 855 & $1,184.0$ & 869.0 & 979.0 & & & \\
\hline 70 & none & $\mathrm{BB} \mathrm{pH} 5.5 \mathrm{w} / 1000 \mathrm{ppm} \mathrm{Gd}$ & & 815 & $1,184.0$ & & 994.6 & & & \\
\hline 89 & none & BB pH $5.5 \mathrm{w} / 10,000 \mathrm{ppm} \mathrm{Gd}$ & 10,800 & 9,072 & 11,843 & $8,396.0$ & $9,483.3$ & & & \\
\hline 90 & none & $\mathrm{BB} \mathrm{pH} 5.5 \mathrm{w} / 10,000 \mathrm{ppm} \mathrm{Gd}$ & & 9,574 & 11,843 & & $8,595.1$ & & & \\
\hline 7 & Cyan & BB Std $\mathrm{pH} 3.5$ & & 0.35 & 182.5 & & 130.6 & 754,930 & $1,188,594$ & $1,637,779$ \\
\hline 8 & Cyan & BB std $\mathrm{pH} 3.5$ & & 0.037 & 182.5 & & 142.8 & 928,396 & $1,149,255$ & $1,657,850$ \\
\hline 27 & Cyan & BB pH $3.5 \mathrm{w} / 10 \mathrm{ppm} \mathrm{Gd}$ & & 2.9 & 11.8 & & 14.0 & 992,836 & 871,073 & $1,811,314$ \\
\hline 28 & Cyan & BB pH $3.5 \mathrm{w} / 10 \mathrm{ppm} \mathrm{Gd}$ & & 3.2 & 11.8 & & 15.9 & 875,396 & $1,401,651$ & $1,342,515$ \\
\hline 47 & Cyan & $\mathrm{BB} \mathrm{pH} 3.5 \mathrm{w} / 100 \mathrm{ppm} \mathrm{Gd}$ & & 2.1 & 118.4 & & 91.9 & 816,882 & 964,737 & 922,949 \\
\hline 48 & Cyan & BB pH $3.5 \mathrm{w} / 100 \mathrm{ppm} \mathrm{Gd}$ & & 1.8 & 118.4 & & 108.9 & 810,861 & 1,039668 & 935,917 \\
\hline 67 & Cyan & BB pH $3.5 \mathrm{w} / 1000 \mathrm{ppm} \mathrm{Gd}$ & & 978 & $1,184.0$ & & 831.4 & 430,853 & 820,896 & 705,991 \\
\hline 68 & Cyan & BB pH $3.5 \mathrm{w} / 1000 \mathrm{ppm} \mathrm{Gd}$ & & 1096 & $1,184.0$ & & 868.2 & 768,043 & 814,875 & 716,528 \\
\hline 87 & Cyan & BB pH $3.5 \mathrm{w} / 10,000 \mathrm{ppm} \mathrm{Gd}$ & & 12,600 & 11,843 & & $9,857.6$ & 647,841 & 612,265 & 629,108 \\
\hline 88 & Cyan & BB pH $3.5 \mathrm{w} / 10,000 \mathrm{ppm} \mathrm{Gd}$ & & 12,814 & 11,843 & & $7,928.1$ & 641,597 & 636,914 & 677,685 \\
\hline 11 & Cyan & C Std $\mathrm{pH} 3.5$ & & 0.18 & 182.5 & & 3.9 & $1,126,642$ & $1,115,937$ & $1,270,706$ \\
\hline 12 & Cyan & C Std $\mathrm{pH} 3.5$ & & 0.28 & 182.5 & & $<1.0$ & 814,875 & $1,206,784$ & $1,661,864$ \\
\hline 31 & Cyan & C pH 3.5 w/10 ppm Gd & & 0.34 & 11.8 & & 10.1 & 671,257 & 890,527 & $1,075,431$ \\
\hline 32 & Cyan & C $\mathrm{pH} 3.5 \mathrm{w} / 10 \mathrm{ppm} \mathrm{Gd}$ & & 0.25 & 11.8 & & 9.8 & $1,032,643$ & 427,508 & $1,256,032$ \\
\hline
\end{tabular}


Table A-5 (Cont.) Experiment \#2 Results

February 23, 2000 WSRC-TR-99-00096

\begin{tabular}{|c|c|c|c|c|c|c|c|c|c|c|}
\hline$\#$ & Alga & Medium & $\begin{array}{c}\text { Gd } \\
(\mathrm{mg} / 1) \\
\text { Before }\end{array}$ & $\begin{array}{c}\text { Gd } \\
(\mathrm{mg} / 1) \\
\text { After }\end{array}$ & $\begin{array}{l}\text { NO3 } \\
(\mathrm{mg} / 1) \\
\text { Est. }\end{array}$ & $\begin{array}{c}\text { NO3 } \\
(\mathrm{mg} / 1) \\
\text { Measured } \\
\text { Before }\end{array}$ & $\begin{array}{c}\text { NO3 } \\
(\mathrm{mg} / \mathrm{l}) \\
\text { Measured } \\
\text { After }\end{array}$ & $\begin{array}{c}\text { Algae } \\
\text { (cells/ } \\
\text { ml) } \\
\text { Inocula } \\
\text { tion }\end{array}$ & $\begin{array}{l}\text { Algae } \\
\text { (cells/ml) } \\
\text { After } 1 \mathrm{wk}\end{array}$ & $\begin{array}{l}\text { Algae } \\
\text { (cells/ml) } \\
\text { After } 2 \text { wk }\end{array}$ \\
\hline 51 & Cyan & C pH $3.5 \mathrm{w} / 100 \mathrm{ppm} \mathrm{Gd}$ & & 0.34 & 118.4 & & 98.0 & $\begin{array}{c}1,136,7 \\
38\end{array}$ & 769,916 & $1,443,594$ \\
\hline 52 & Cyan & $\mathrm{C} \mathrm{pH} 3.5 \mathrm{w} / 100 \mathrm{ppm} \mathrm{Gd}$ & & 0.16 & 118.4 & & 96.7 & 788,649 & 808,854 & 768,043 \\
\hline 71 & Cyan & $\mathrm{C} \mathrm{pH} 3.5 \mathrm{w} / 1000 \mathrm{ppm} \mathrm{Gd}$ & & 804 & $1,184.0$ & & 930.4 & 666,574 & 946,004 & $1,002,203$ \\
\hline 72 & Cyan & $\mathrm{C} \mathrm{pH} 3.5 \mathrm{w} / 1000 \mathrm{ppm} \mathrm{Gd}$ & & 714 & $1,184.0$ & & 946.8 & 584,462 & 799,889 & 927,272 \\
\hline 91 & Cyan & $\mathrm{C} \mathrm{pH} 3.5 \mathrm{w} / 10,000 \mathrm{ppm} \mathrm{Gd}$ & & 12,398 & 11,843 & & $9,709.5$ & 638,475 & 771,790 & 600,434 \\
\hline 92 & Cyan & $\mathrm{C} \mathrm{pH} 3.5 \mathrm{w} / 10,000 \mathrm{ppm} \mathrm{Gd}$ & & 13,020 & 11,843 & & $8,396.9$ & 595,702 & 699,173 & 627,054 \\
\hline 13 & none & C std $\mathrm{pH} 3.5$ & 0.17 & 0.15 & 182.5 & ND & ND & & & \\
\hline 14 & none & C std $\mathrm{pH} 3.5$ & & 0.11 & 182.5 & & ND & & & \\
\hline 33 & none & $\mathrm{C} \mathrm{pH} 3.5 \mathrm{w} / 10 \mathrm{ppm} \mathrm{Gd}$ & 10.4 & 0.12 & 11.8 & 1.4 & 10.5 & & & \\
\hline 34 & none & $\mathrm{C} \mathrm{pH} 3.5 \mathrm{w} / 10 \mathrm{ppm} \mathrm{Gd}$ & & 2 & 11.8 & & 13.0 & & & \\
\hline 53 & none & $\mathrm{C} \mathrm{pH} 3.5 \mathrm{w} / 100 \mathrm{ppm} \mathrm{Gd}$ & 91.9 & 0.09 & 118.4 & 16.0 & 97.0 & & & \\
\hline 73 & none & $\mathrm{C} \mathrm{pH} 3.5 \mathrm{w} / 1000 \mathrm{ppm} \mathrm{Gd}$ & 838 & 788 & $1,184.0$ & 1,2960 & 909.3 & & & \\
\hline 74 & none & $\mathrm{C} \mathrm{pH} 3.5 \mathrm{w} / 1000 \mathrm{ppm} \mathrm{Gd}$ & & 774 & $1,184.0$ & & 927.9 & & & \\
\hline 93 & none & $\mathrm{C} \mathrm{pH} 3.5 \mathrm{w} / 10,000 \mathrm{ppm} \mathrm{Gd}$ & 9340 & 14,010 & 11,843 & 12,996 & $10,305.6$ & & & \\
\hline 94 & none & C pH 3.5 w/10,000 ppm Gd & & 12,500 & 11,843 & & $9,631.1$ & & & \\
\hline 15 & Mast 113D & ND Std pH 5.5 & & 0.1 & 0 & & $\mathrm{ND}$ & & & \\
\hline 16 & Mast 113D & ND std $\mathrm{pH} 5.5$ & & 0.74 & 0 & & 2.0 & & & \\
\hline 35 & Mast 113D & ND $\mathrm{pH} 5.5 \mathrm{w} / 10 \mathrm{ppm}$ Gd & & 2.9 & 11.8 & & 10.7 & & & \\
\hline 36 & Mast 113D & ND $\mathrm{pH} 5.5 \mathrm{w} / 10 \mathrm{ppm}$ Gd & & 3.1 & 11.8 & & 11.4 & & & \\
\hline 55 & Mast $113 \mathrm{D}$ & ND $\mathrm{pH} 5.5 \mathrm{w} / 100 \mathrm{ppm} \mathrm{Gd}$ & & 17.2 & 118.4 & & 149.4 & & & \\
\hline 56 & Mast 113D & ND $\mathrm{pH} 5.5 \mathrm{w} / 100 \mathrm{ppm} \mathrm{Gd}$ & & 19.7 & 118.4 & & 154.3 & & & \\
\hline 75 & Mast 113D & $\mathrm{ND} \mathrm{pH} 5.5 \mathrm{w} / 1000 \mathrm{ppm} \mathrm{Gd}$ & & 1822 & $1,184.0$ & & $1,462.5$ & & & \\
\hline 76 & Mast 113D & ND $\mathrm{pH} 5.5 \mathrm{w} / 1000 \mathrm{ppm} \mathrm{Gd}$ & & 1517 & $1,184.0$ & & $1,477.1$ & & & \\
\hline 95 & Mast 113D & ND pH 5.5 w/10,000 ppm Gd & & 14,450 & 11,843 & & $14,236.3$ & & & \\
\hline 96 & Mast 113D & ND pH 5.5 w/10,000 ppm Gd & & 19,340 & 11,843 & & $14,466.3$ & & & \\
\hline 18 & Mast M1 & ND std $\mathrm{pH} 5.5$ & & 0.09 & 0 & & 1.6 & & & \\
\hline 37 & Mast M1 & ND $\mathrm{pH} 5.5 \mathrm{w} / 10 \mathrm{ppm}$ Gd & & 3.1 & 11.8 & & 1.9 & & & \\
\hline 38 & Mast M1 & ND $\mathrm{pH} 5.5 \mathrm{w} / 10 \mathrm{ppm} \mathrm{Gd}$ & & 3 & 11.8 & & $\mathrm{ND}$ & & & \\
\hline 57 & Mast M1 & ND $\mathrm{pH} 5.5 \mathrm{w} / 100 \mathrm{ppm} \mathrm{Gd}$ & & 19 & 118.4 & & 140.1 & & & \\
\hline 58 & Mast M1 & ND $\mathrm{pH} 5.5 \mathrm{w} / 100 \mathrm{ppm} \mathrm{Gd}$ & & 20.7 & 118.4 & & 149.0 & & & \\
\hline 77 & Mast M1 & ND $\mathrm{pH} 5.5 \mathrm{w} / 1000 \mathrm{ppm} \mathrm{Gd}$ & & 1380 & $1,184.0$ & & $1,478.0$ & & & \\
\hline 78 & Mast M1 & $\mathrm{ND} \mathrm{pH} 5.5 \mathrm{w} / 1000 \mathrm{ppm} \mathrm{Gd}$ & & 1531 & $1,184.0$ & & $1,541.2$ & & & \\
\hline 97 & Mast M1 & ND pH $5.5 \mathrm{w} / 10,000 \mathrm{ppm} \mathrm{Gd}$ & & 19,490 & $11,843$. & & $13,968.0$ & & & \\
\hline 98 & Mast M1 & ND $\mathrm{pH} 5.5 \mathrm{w} / 10,000 \mathrm{ppm} \mathrm{Gd}$ & & 14,480 & 11,843 & & $9,121.4$ & & & \\
\hline 19 & none & ND std $\mathrm{pH} 5.5$ & $<0.05$ & 1 & & $<1$ & 2.2 & & & \\
\hline 20 & none & ND Std $\mathrm{pH} 5.5$ & & $<0.05$ & & & 2.3 & & & \\
\hline 39 & none & ND $\mathrm{pH} 5.5 \mathrm{w} / 10 \mathrm{ppm} \mathrm{Gd}$ & 9.4 & 3 & 11.8 & 1.8 & 17.9 & & & \\
\hline 40 & none & $\mathrm{ND} \mathrm{pH} 5.5 \mathrm{w} / 10 \mathrm{ppm} \mathrm{Gd}$ & & 3.8 & 11.8 & & 21.4 & & & \\
\hline 59 & none & $\mathrm{ND} \mathrm{pH} 5.5 \mathrm{w} / 100 \mathrm{ppm} \mathrm{Gd}$ & 87.7 & 16.9 & 118.4 & 17.0 & 152.7 & & & \\
\hline 79 & none & $\mathrm{ND} \mathrm{pH} 5.5 \mathrm{w} / 1000 \mathrm{ppm} \mathrm{Gd}$ & 895 & 1546 & $1,184.0$ & 896.0 & $1,505.0$ & & & \\
\hline 80 & none & $\mathrm{ND} \mathrm{pH} 5.5 \mathrm{w} / 1000 \mathrm{ppm} \mathrm{Gd}$ & & 1731 & $1,184.0$ & & $1,556.1$ & & & \\
\hline 60 & none & ND $\mathrm{pH} 5.5 \mathrm{w} / 100 \mathrm{ppm}$ Gd & & 125 & 118.4 & & 153.4 & & & \\
\hline 99 & none & ND $\mathrm{pH} 5.5 \mathrm{w} / 10,000 \mathrm{ppm} \mathrm{Gd}$ & 10,185 & 17,890 & 11,843 & $11,306.0$ & $6,786.9$ & & & \\
\hline 100 & none & $\mathrm{ND} \mathrm{pH} 5.5 \mathrm{w} / 10,000 \mathrm{ppm} \mathrm{Gd}$ & & 17,670 & 11,843 & & $3,401.3$ & & & \\
\hline
\end{tabular}


Table A-6 Experiment \#3 Results (Growth of Chlorella in different media formulations)

\begin{tabular}{|c|c|c|c|c|c|c|c|}
\hline Sample Num & & $\# 1-48$ & $\# 49-96$ & $\# 97-144$ & & & \\
\hline BB Media variations & $\begin{array}{l}\mathrm{NO}_{3}(\mathrm{mg} / \mathrm{l}) \\
\text { Estimate. }\end{array}$ & \begin{tabular}{|l|}
$\mathrm{NO}_{3}$ \\
$(\mathrm{mg} / \mathrm{l})$ \\
$\mathrm{Meas}$. \\
Before \\
\end{tabular} & $\begin{array}{l}\mathrm{NO}_{3}(\mathrm{mg} / \mathrm{l}) \\
\text { Measured. } \\
\text { After Algal } \\
\text { Growth } \\
\end{array}$ & $\begin{array}{l}\mathrm{NO}_{3}(\mathrm{mg} / \mathrm{l}) \\
\text { Meas. After } \\
\text { Treatment W/ } \\
\text { No Algae } \\
\end{array}$ & $\begin{array}{l}\text { Algae (cells } / \mathrm{ml} \text { ) } \\
\text { Inoculation }\end{array}$ & \begin{tabular}{|l|} 
Algae \\
(cells/ml) \\
after 1-week
\end{tabular} & Growth? \\
\hline $10 \mathrm{ppm} \mathrm{Gd}$ as $\mathrm{GdNO}_{3}$ & 11.8 & 24.7 & $\begin{array}{l}0.7 \\
\end{array}$ & 10.4 & $3.61 \mathrm{E}+05$ & $1.19 E+06$ & $\mathrm{x}$ \\
\hline 10 ppm Gd as $\mathrm{GdNO}_{3}$ & 11.8 & 25.1 & $<0.1$ & 12 & $3.61 \mathrm{E}+05$ & & \\
\hline 10 ppm Gd as $\mathrm{GdNO}_{3}$ & 11.8 & 26.2 & $<0.1$ & 12.5 & $3.61 \mathrm{E}+05$ & $9.58 \mathrm{E}+05$ & $x$ \\
\hline 100 ppm Gd as $\mathrm{GdNO}_{3}$ & 118 & 38.9 & 17 & 32.3 & $3.61 \mathrm{E}+05$ & $9.92 \mathrm{E}+05$ & $\mathrm{x}$ \\
\hline 100 ppm Gd as $\mathrm{GdNO}_{3}$ & 118 & 37.7 & 19.5 & 44 & $3.61 \mathrm{E}+05$ & & \\
\hline 100 ppm Gd as $\mathrm{GdNO}_{3}$ & 118 & 35.5 & 26.1 & 16 & $3.61 \mathrm{E}+05$ & $8.71 \mathrm{E}+05$ & $\mathrm{x}$ \\
\hline 1000 ppm Gd as $\mathrm{GdNO}_{3}$ & 1180 & 1106 & 2167 & 11,753 & $3.61 \mathrm{E}+05$ & $3.64 \mathrm{E}+05$ & $x$ \\
\hline 1000 ppm Gd as $\mathrm{GdNO}_{3}$ & 1180 & 1114 & 2432 & 13,773 & $3.61 \mathrm{E}+05$ & & \\
\hline 1000 ppm Gd as $\mathrm{GdNO}_{3}$ & 1180 & 1075 & 2314 & 13,196 & $3.61 \mathrm{E}+05$ & $3.86 \mathrm{E}+05$ & $\mathrm{x}$ \\
\hline $10,000 \mathrm{ppm}$ Gd as $\mathrm{GdNO}_{3}$ & 11800 & 10715 & 11,586 & 12,423 & $3.61 \mathrm{E}+05$ & $3.24 \mathrm{E}+05$ & 0 \\
\hline 10,000 ppm Gd as $\mathrm{GdNO}_{3}$ & 11800 & 10630 & 11,629 & 11,993 & $3.61 \mathrm{E}+05$ & & \\
\hline $10,000 \mathrm{ppm}$ Gd as $\mathrm{GdNO}_{3}$ & 11800 & 10302 & 11,344 & 12,617 & $3.61 \mathrm{E}+05$ & $3.06 \mathrm{E}+05$ & 0 \\
\hline $10 \mathrm{ppm} \mathrm{Na}$ as $\mathrm{NaNO}_{3}$ & 26.95 & 27.8 & 7.4 & 27.8 & $3.61 \mathrm{E}+05$ & $6.96 \mathrm{E}+05$ & $x$ \\
\hline 10 ppm Na as $\mathrm{NaNO}_{3}$ & 26.95 & 27.4 & $<0.1$ & 26.8 & $3.61 \mathrm{E}+05$ & & \\
\hline 10 ppm $\mathrm{Na}$ as $\mathrm{NaNO}_{3}$ & 26.95 & 27 & 0.84 & 27.2 & $3.61 \mathrm{E}+05$ & $6.56 \mathrm{E}+05$ & $\mathrm{x}$ \\
\hline 100 ppm $\mathrm{Na}$ as $\mathrm{NaNO}_{3}$ & 269.5 & 68.2 & 38.6 & 74.1 & $3.61 \mathrm{E}+05$ & $2.79 \mathrm{E}+06$ & $x$ \\
\hline 100 ppm $\mathrm{Na}$ as $\mathrm{NaNO}_{3}$ & 269.5 & 71.7 & 62.4 & 74.5 & $3.61 \mathrm{E}+05$ & & \\
\hline 100 ppm $\mathrm{Na}$ as $\mathrm{NaNO}_{3}$ & 269.5 & 35.4 & 49.3 & 76 & $3.61 \mathrm{E}+05$ & $5.46 \mathrm{E}+05$ & $x$ \\
\hline 1000 ppm $\mathrm{Na}$ as $\mathrm{NaNO}_{3}$ & 2695 & 3676 & 1815 & 1959 & $3.61 \mathrm{E}+05$ & $9.79 \mathrm{E}+05$ & $\mathrm{x}$ \\
\hline 1000 ppm $\mathrm{Na}$ as $\mathrm{NaNO}_{3}$ & 2695 & 3561 & 1748 & 1871 & $3.61 \mathrm{E}+05$ & $8.03 E+05$ & $\mathrm{x}$ \\
\hline 1000 ppm $\mathrm{Na}$ as $\mathrm{NaNO}_{3}$ & 2695 & 3434 & cancel & 1908 & $3.61 \mathrm{E}+05$ & & \\
\hline $10,000 \mathrm{ppm} \mathrm{Na}$ as $\mathrm{NaNO}_{3}$ & 26950 & 20250 & 19,079 & 20,362 & $3.61 \mathrm{E}+05$ & $6.63 E+05$ & $\mathrm{x}$ \\
\hline $10,000 \mathrm{ppm} \mathrm{Na}$ as $\mathrm{NaNO}_{3}$ & 26950 & 17631 & 14,434 & 21,259 & $3.61 \mathrm{E}+05$ & & \\
\hline $10,000 \mathrm{ppm} \mathrm{Na}$ as $\mathrm{NaNO}_{3}$ & 26950 & 19946 & 19,189 & 21,899 & $3.61 \mathrm{E}+05$ & $5.22 \mathrm{E}+05$ & $x$ \\
\hline $10 \mathrm{ppm} \mathrm{K}$ as $\mathrm{KNO}_{3}$ & 15.89 & 3487 & 549 & 3.7 & $3.61 \mathrm{E}+05$ & & \\
\hline $10 \mathrm{ppm} \mathrm{K}$ as $\mathrm{KNO}_{3}$ & 15.89 & 3349 & 18.1 & 4.3 & $3.61 \mathrm{E}+05$ & $3.84 \mathrm{E}+05$ & $x$ \\
\hline $10 \mathrm{ppm} \mathrm{K}$ as $\mathrm{KNO}_{3}$ & 15.89 & 3488 & 8.1 & 11.6 & $3.61 \mathrm{E}+05$ & $8.85 E+05$ & $x$ \\
\hline $100 \mathrm{ppm} \mathrm{K}$ as $\mathrm{KNO}_{3}$ & 158.9 & 190 & 60.3 & 97 & $3.61 \mathrm{E}+05$ & & \\
\hline $100 \mathrm{ppm} \mathrm{K}$ as $\mathrm{KNO}_{3}$ & 158.9 & 214 & 53.8 & 98 & $3.61 E+05$ & $1.93 E+06$ & $\mathrm{x}$ \\
\hline $100 \mathrm{ppm} \mathrm{K}$ as $\mathrm{KNO}_{3}$ & 158.9 & 197 & 65.8 & 98 & $3.61 \mathrm{E}+05$ & $9.49 \mathrm{E}+05$ & $x$ \\
\hline $1000 \mathrm{ppm} \mathrm{K}$ as $\mathrm{KNO}_{3}$ & 1589 & 1328 & 1261 & 1259 & $3.61 \mathrm{E}+05$ & & \\
\hline $1000 \mathrm{ppm} \mathrm{K}$ as $\mathrm{KNO}_{3}$ & 1589 & 1334 & 1307 & 1392 & $3.61 \mathrm{E}+05$ & $7.96 \mathrm{E}+05$ & $\mathrm{x}$ \\
\hline 1000 ppm K as $\mathrm{KNO}_{3}$ & 1589 & 1317 & 1324 & 1371 & $3.61 \mathrm{E}+05$ & $8.21 E+05$ & $x$ \\
\hline 10,000 ppm $\mathrm{K}$ as $\mathrm{KNO}_{3}$ & 15890 & 19877 & 14,316 & 14,950 & $3.61 E+05$ & & \\
\hline
\end{tabular}


Table A-6 (Continued) Experiment \#3 Results (Growth of Chlorella in different media formulations)

\begin{tabular}{|c|c|c|c|c|c|c|c|}
\hline \multicolumn{2}{|l|}{ Sample Numbers } & $\# 1-48$ & $\# 49-96$ & \#97-144 & & & \\
\hline BB Media variations & $\mathrm{NO}_{3}$ Est. & & $\begin{array}{l}\mathrm{NO}_{3} \text { Meas. } \\
(\mathrm{mg} / \mathrm{l}) \text { After } \\
\text { Algal } \\
\text { Growth }\end{array}$ & $\begin{array}{l}\mathrm{NO}_{3} \text { Meas. } \\
\text { (mg/l) After } \\
\text { Treatment W/ } \\
\text { No Algae }\end{array}$ & $\begin{array}{l}\text { Algal } \\
\text { Inoculation } \\
\text { (cells/ml) }\end{array}$ & $\begin{array}{l}\text { Algae at } 1 \\
\text { wk (cells } / \mathrm{ml}\end{array}$ & \\
\hline $10,000 \mathrm{ppm} \mathrm{K}$ as $\mathrm{KNO}_{3}$ & 15890 & 13863 & 14,178 & 14,728 & $3.61 \mathrm{E}+05$ & $6.66 \mathrm{E}+05$ & $\mathrm{x}$ \\
\hline $10,000 \mathrm{ppm} \mathrm{K}$ as $\mathrm{KNO}_{3}$ & 15890 & 14550 & 14,271 & 14,231 & $3.61 \mathrm{E}+05$ & $6.00 \mathrm{E}+05$ & $x$ \\
\hline 10 ppm NH4 as $\mathrm{NH}_{4} \mathrm{NO}_{3}$ & 34.44 & 5.8 & 180 & 6 & $3.61 \mathrm{E}+05$ & $7.70 \mathrm{E}+05$ & $x$ \\
\hline $10 \mathrm{ppm} \mathrm{NH} 4$ as $\mathrm{NH}_{4} \mathrm{NO}_{3}$ & 34.44 & 9.2 & 2.4 & 5.2 & $3.61 \mathrm{E}+05$ & $4.19 \mathrm{E}+05$ & $x$ \\
\hline $10 \mathrm{ppm} \mathrm{NH} 4$ as $\mathrm{NH}_{4} \mathrm{NO}_{3}$ & 34.44 & 8.5 & 5.9 & 4.8 & $3.61 \mathrm{E}+05$ & & \\
\hline 100 ppm NH4 as $\mathrm{NH}_{4} \mathrm{NO}_{3}$ & 344.4 & 305 & 325 & 311 & $3.61 E+05$ & $6.35 \mathrm{E}+05$ & $\mathrm{x}$ \\
\hline $100 \mathrm{ppm} \mathrm{NH4}$ as $\mathrm{NH}_{4} \mathrm{NO}_{3}$ & 344.4 & 325 & 308 & 317 & $3.61 \mathrm{E}+05$ & $3.85 \mathrm{E}+05$ & $\mathrm{x}$ \\
\hline 100 ppm NH4 as $\mathrm{NH}_{4} \mathrm{NO}_{3}$ & 344.4 & 308 & 319 & 321 & $3.61 \mathrm{E}+05$ & & \\
\hline 1000 ppm NH4 as $\mathrm{NH}_{4} \mathrm{NO}_{3}$ & 3444 & 3135 & 3232 & 3176 & $3.61 \mathrm{E}+05$ & $5.42 \mathrm{E}+05$ & $x$ \\
\hline 1000 ppm NH4 as $\mathrm{NH}_{4} \mathrm{NO}_{3}$ & 3444 & 3545 & 3284 & 3191 & $3.61 \mathrm{E}+05$ & $2.74 \mathrm{E}+05$ & 0 \\
\hline 1000 ppm NH4 as $\mathrm{NH}_{4} \mathrm{NO}_{3}$ & 3444 & 3117 & Cancel & 3225 & $3.61 \mathrm{E}+05$ & & \\
\hline 10,000 ppm NH4 as $\mathrm{NH}_{4} \mathrm{NO}_{3}$ & 34440 & 32736 & 34,019 & 32,174 & $361+\mathrm{E}+05$ & $321 \mathrm{E}+05$ & 0 \\
\hline 10,000 ppm NH4 as $\mathrm{NH}_{4} \mathrm{NO}_{3}$ & 34440 & 31291 & 49,769 & 36,819 & $3.61 \mathrm{E}+05$ & $2.35 \mathrm{E}+05$ & 0 \\
\hline 10,000 ppm NH4 as $\mathrm{NH}_{4} \mathrm{NO}_{3}$ & 34440 & 29839 & 34,778 & 35,651 & $3.61 \mathrm{E}+05$ & & \\
\hline
\end{tabular}

